\title{
Scaling precipitation extremes with temperature in the Mediterranean: past climate assessment and projection in anthropogenic scenarios
}

\author{
Philippe Drobinski ${ }^{1}$ Nicolas Da Silva ${ }^{1}$ - Gérémy Panthou ${ }^{2} \cdot$ Sophie Bastin $^{3}$. \\ Caroline Muller $^{4} \cdot$ Bodo Ahrens $^{5} \cdot$ Marco Borga $^{6} \cdot$ Dario Conte $^{7} \cdot$ Giorgia Fosser $^{8}$. \\ Filippo Giorgi ${ }^{9}$ Ivan Güttler ${ }^{10}$ • Vassiliki Kotroni ${ }^{11}$ • Laurent Li $^{12}$ • Efrat Morin ${ }^{13}$. \\ Bariş Önol $^{14} \cdot$ Pere Quintana-Segui $^{15} \cdot$ Raquel Romera $^{16} \cdot$ Csaba Zsolt Torma9 $^{9}$
}

Received: 31 July 2015 / Accepted: 12 March 2016 / Published online: 26 March 2016

(C) The Author(s) 2016. This article is published with open access at Springerlink.com

\begin{abstract}
In this study we investigate the scaling of precipitation extremes with temperature in the Mediterranean region by assessing against observations the present day and future regional climate simulations performed in the frame of the HyMeX and MED-CORDEX programs. Over the 1979-2008 period, despite differences in quantitative precipitation simulation across the various models, the change in precipitation extremes with respect to temperature is robust and consistent. The spatial variability of the
\end{abstract}

This paper is a contribution to the special issue on MedCORDEX, an international coordinated initiative dedicated to the multi-component regional climate modelling (atmosphere, ocean, land surface, river) of the Mediterranean under the umbrella of HyMeX, CORDEX, and Med-CLIVAR and coordinated by Samuel Somot, Paolo Ruti, Erika Coppola, Gianmaria Sannino, Bodo Ahrens, and Gabriel Jordà.

Philippe Drobinski

philippe.drobinski@1md.polytechnique.fr

1 LMD/IPSL, CNRS and École Polytechnique, Université Paris-Saclay, Palaiseau, France

2 LSCE/IPSL, CNRS and CEA, Université Paris-Saclay, Gif sur Yvette, France

3 LATMOS/IPSL, UVSQ, UPMC Univ. Paris 06, CNRS/ INSU, Université Paris-Saclay, Sorbonne Universités , Guyancourt, France

4 LadHyX, CNRS and Ecole Polytechnique, Université Paris-Saclay, Palaiseau, France

5 Institute for Atmospheric and Environmental Sciences, Goethe-University Frankfurt, Frankfurt, Germany

6 Department of Land and Agroforest Environments, University of Padova, Legnaro, Italy

7 CMCC, Lecce, Italy

8 Météo-France/CNRM, CNRS/GAME, Toulouse, France temperature-precipitation extremes relationship displays a hook shape across the Mediterranean, with negative slope at high temperatures and a slope following Clausius-Clapeyron (CC)-scaling at low temperatures. The temperature at which the slope of the temperature-precipitation extreme relation sharply changes (or temperature break), ranges from about $20{ }^{\circ} \mathrm{C}$ in the western Mediterranean to $<10{ }^{\circ} \mathrm{C}$ in Greece. In addition, this slope is always negative in the arid regions of the Mediterranean. The scaling of the simulated precipitation extremes is insensitive to oceanatmosphere coupling, while it depends very weakly on the resolution at high temperatures for short precipitation accumulation times. In future climate scenario simulations covering the 2070-2100 period, the temperature break shifts to higher temperatures by a value which is on average the mean regional temperature change due to global warming.

9 Abdus Salam International Centre for Theoretical Physics, Trieste, Italy

10 Meteorological and Hydrological Service of Croatia (DHMZ), Zagreb, Croatia

11 Institute for Environmental Research and Sustainable Development, National Observatory of Athens, Athens, Greece

12 LMD/IPSL, CNRS and UPMC Univ Paris 06, Sorbonne Université, Paris, France

13 Geography Department, The Hebrew University of Jerusalem, Mt. Scopus, Jerusalem, Israel

14 Department of Meteorology, Aeronautics and Astronautics Faculty, Istanbul Technical University, Maslak, Istanbul, Turkey

15 Observatori de l'Ebre, Universitat Ramon LLull - CSIC, Roquetes, Tarragona, Spain

16 Environmental Sciences Institute, University of Castilla-La Mancha, Toledo, Spain 
The slope of the simulated future temperature-precipitation extremes relationship is close to CC-scaling at temperatures below the temperature break, while at high temperatures, the negative slope is close, but somewhat flatter or steeper, than in the current climate depending on the model. Overall, models predict more intense precipitation extremes in the future. Adjusting the temperature-precipitation extremes relationship in the present climate using the CC law and the temperature shift in the future allows the recovery of the temperature-precipitation extremes relationship in the future climate. This implies negligible regional changes of relative humidity in the future despite the large warming and drying over the Mediterranean. This suggests that the Mediterranean Sea is the primary source of moisture which counteracts the drying and warming impacts on relative humidity in parts of the Mediterranean region.

Keywords Precipitation extremes - Clausius-Clapeyron scaling $\cdot$ Regional climate $\cdot$ Europe $\cdot$ Mediterranean . HyMeX $\cdot$ MED-CORDEX

\section{Introduction}

The complex geography of the Mediterranean region, which features a nearly enclosed sea with high sea surface temperature during summer and fall surrounded by mountains (Fig. 1), plays a crucial role in steering airflow producing heavy precipitation and catastrophic floods (e.g. Delrieu et al. 2005; Jonkman 2005; Ducrocq et al.
2008; Papagiannaki et al. 2013). In the last 50 years significant increasing trends in daily torrential rains was observed in some western Mediterranean regions, while in the east relatively high interannual variability prevents any trend from being significant (Alpert et al. 2002).

Precipitation extremes and flash floodings are among the most devastating natural hazards in terms of mortality (e.g. Jonkman 2005). Even if flash floods are usually small-scale events, their suddenness and violence account for the high proportion of human losses. According to Jonkman (2005), the European and African continents display the highest mortality rates due to floods or flash floods in the world. Precipitation intensity is projected to increase in most regions under warmer climates, and the increase in precipitation extremes will be larger than that in the mean precipitation (Meehl et al. 2007), with large impacts on society (Oki and Kanae 2006; Pall et al. 2011; Min et al. 2011). In the Mediterranean region, observations (e.g. Quereda Sala et al. 2000; Xoplaki et al. 2003; Shohami et al. 2011) as well as the majority of twenty-first century scenarios show a warming and drying of the Mediterranean. The scenarios show a decrease in average precipitation with a peak signal in summer with either atmosphere-ocean Global Climate Models (GCM) (Giorgi and Bi 2005) or atmosphere Regional Climate Models (Gibelin and Déqué 2003; Déqué et al. 2005; Gao et al. 2006; Ulbrich et al. 2006) and coupled atmosphere-ocean Regional Climate Models (RCM) (Somot et al. 2008). There is, however, no consensus on the evolution of the frequency and intensity of the extreme events over the Mediterranean, even though a decrease of average precipitation and an increase in precipitation variability is expected (Pal et al. 2004; Giorgi 2006;

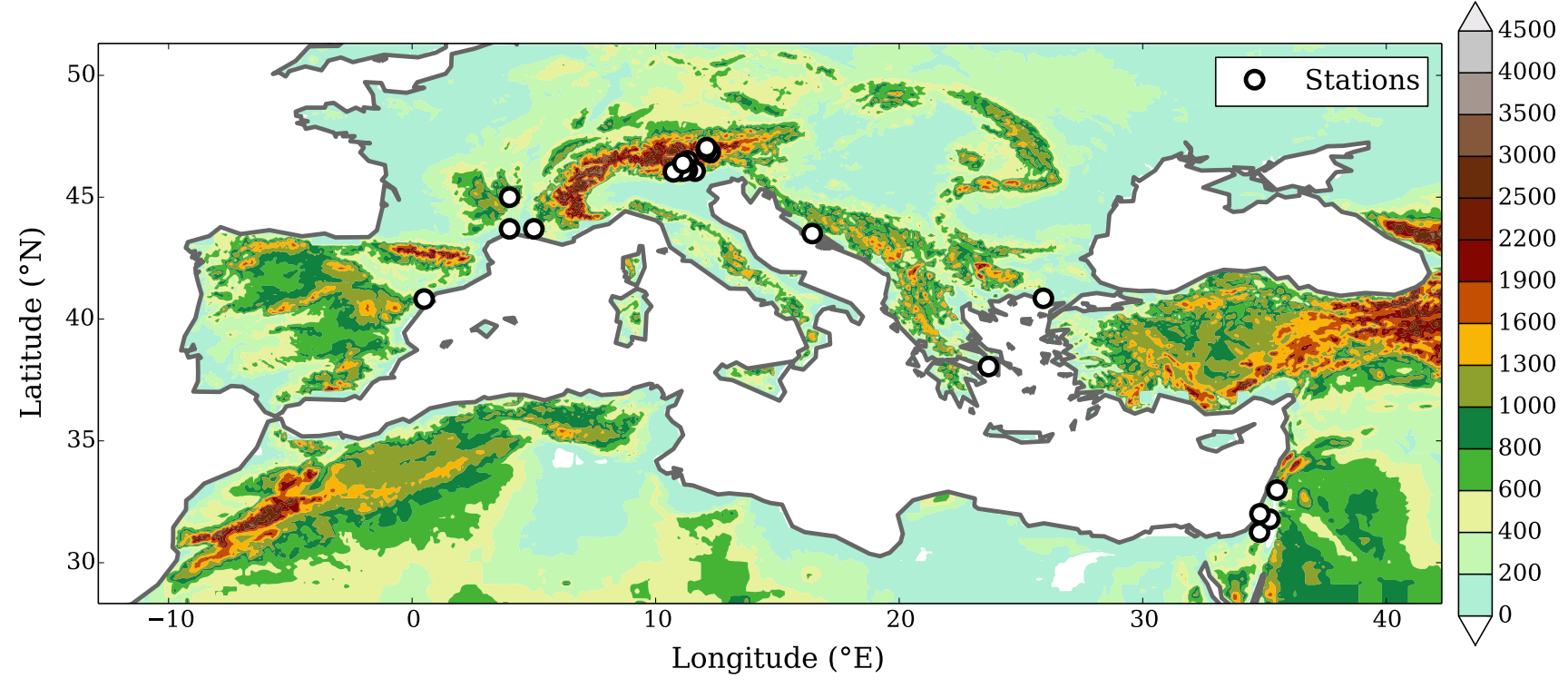

Fig. 1 Target region of the HyMeX/MED-CORDEX regional climate simulations with colors indicating the topography and white circles the locations of the weather stations used in this study 
Lavaysse et al. 2012; Önol et al. 2014) and an increased probability of occurrence of events conducive to floods has been suggested (Gao et al. 2006).

The Clausius-Clapeyron (CC) relation has been used as a predictor of changes in extreme precipitation with global warming. Indeed, the increase in the saturation water vapor pressure associated with warming is described by the $\mathrm{CC}$ relation:

$\frac{\partial e_{s}}{\partial T}=\frac{L_{v} e_{s}}{R_{v} T^{2}}$

where $e_{S}$ is the saturation water vapor pressure, $T$ is the absolute atmospheric temperature in Kelvin, $L_{v}$ is the latent heat of vaporization and $R_{v}$ is the gas constant. The CC relation considerably influences the changes in the extreme precipitation intensity under warmer climates (Betts and Harshvardhan 1987; Trenberth et al. 2003; Held and Soden 2006; Pall et al. 2007; Kharin et al. 2007; O'Gorman and Muller 2010; Muller et al. 2011; Romps 2011; Westra et al. 2014). Considering this, observed relations between extreme precipitation and temperature have received considerable attention. In the French Mediterranean region, Drobinski et al. (2016) showed that the scaling of precipitation extreme displays a hook-like shape with a nearly CC-scaling at low temperatures and a negative slope at high temperatures, which they attribute to the arid environment in summer. Deviations from the CC scaling have been observed or simulated for several reasons such as precipitation accumulation duration (Utsumi et al. 2011; Drobinski et al. 2016), use of surface air temperature as a proxy of the tropospheric temperature (Hardwick Jones et al. 2010; Drobinski et al. 2016), change in precipitation type (Haerter and Berg 2009; Berg and Haerter 2013), changes in the atmospheric dynamics (O'Gorman and Schneider 2009; Sugiyama et al. 2010; Singleton and Toumi 2013; Muller 2013) which may be related to seasonal variability (Berg et al. 2009; Drobinski et al. 2016). Hence, the applicability of the CC scaling on the temperature-precipitation extremes relationship is still uncertain. Indeed, there is a need to distinguish two different concepts. On the one hand, there is the long term conception that changes in precipitation extremes in a warming climate scale with the $\mathrm{CC}$ relation, such as discussed in Allen and Ingram (2002) and referred as "projected" scaling in the following. On the other hand, there are studies, among which those referenced above, which link precipitation extremes to the daily mean temperature in present-day observations. This relation is referred as "observed" scaling in the following. It is not trivial that these two are connected and that deviations from the thermodynamic $\mathrm{CC}$ behavior have similar origins.

This study focuses on the scaling of precipitation extremes with temperature throughout the Mediterranean region, based on quality controlled measurements of surface temperature and precipitation at various weather stations around the Mediterranean, fine-scale gridded observational datasets and simulations performed within the context of the HyMeX (Drobinski et al. 2014) and MED-CORDEX programs (Ruti et al. 2015) for present day and future climate. Our main objective is to investigate the temporal and spatial variability of the scaling and more precisely, to address the following questions:

- What is the spatial variability of the "observed" scaling of precipitation extremes with temperature around the Mediterranean basin characterized by coastal areas, plains and high mountain ranges, and under the influence of arid and mid-latitude climates?

- What is the uncertainty associated with the simulated "observed" and "projected" scalings of precipitation extremes?

- What are the possible skill changes at high resolution relative to low resolution and the possible effects of ocean-atmosphere feedbacks on the simulated "observed" and "projected" scaling of precipitation extremes?

- How much and why do the "observed" scaling in present-day and "projected" scaling in anthropogenic scenario differ?

Section 2 details our data (observations and simulations) and analysis methods. Section 3 investigates the ability of the regional climate models to simulate the dependence of precipitation extremes on temperature, its sensitivity to precipitation accumulation duration, model resolution and ocean-atmosphere feedbacks, and its spatial variability within the Mediterranean region. Section 4 analyzes the evolution of the scaling of precipitation extremes in the context of climate change, while Sect. 5 discusses some open research questions needing further investigation.

\section{Material and methods}

\subsection{Methodology}

Several methodologies have been used to characterize the scaling of precipitation extremes with temperature. Here we follow the method proposed by Hardwick Jones et al. (2010) and used in Drobinski et al. (2016), and apply it to time series of temperature and precipitation from three different sources: (1) in-situ measurements from surface weather stations across the Mediterranean basin, (2) E-OBS gridded data products and (3) regional climate simulations. At each station for a given precipitation duration (daily or subdaily), the maximum recorded precipitation rate on each rainy period is paired with the daily mean air 
temperature at $2 \mathrm{~m}$ above the ground level. Subdaily intensities are also binned using the daily mean $2 \mathrm{~m}$ temperature instead of subdaily temperatures, since we are interested in a proxy representing the temperature of the air mass and for consistency with previous studies. For temperature in the E-OBS dataset and the regional climate simulations, we use the output of the grid point closest to the station location. The precipitation-temperature pairs are placed in bins according to temperature, with an equal number of samples in each bin (100 samples) and therefore varying temperature ranges for each bin. A sensitivity analysis was conducted with increasing numbers of samples up to 200 without any significant differences. The value of 100 samples was finally used as the best trade-off between the temperature-range sampling and the accuracy of the precipitation extreme estimate. The mean temperature of the events in each bin is used as the representative temperature for that bin. Within each bin of 100 samples, precipitation intensities are ranked to determine the 99th percentile. An exponential regression is applied to the precipitation values for each percentile (by fitting a least-squared linear regression to the logarithm of precipitation depth) to derive the slope of the temperature-precipitation extremes relationship. When this slope is 0.0596 , it is equivalent to a Clausius-Clapeyron-like scaling of $5.96 \%{ }^{\circ} \mathrm{C}^{-1}$ at $25{ }^{\circ} \mathrm{C}$.

\subsection{Observations: E-OBS dataset}

The temperature and precipitation series used in this study come from the E-OBS gridded dataset (Haylock et al. 2008), which was obtained through an interpolation procedure described in Haylock et al. (2008) from the ECA\&D recorded series (Klok and Klein Tank 2009). We use here the version 10 of this product (released date: April 2014). The dataset covers Europe from 1950 to 2013 at a daily time-step with a spatial resolution of $0.25^{\circ}$. E-OBS has been widely used for regional climate model evaluation (e.g. Lorenz and Jacob 2010; Kjellström et al. 2011;
Nikulin et al. 2011; Samuelsson et al. 2011; Torma et al. 2011; Flaounas et al. 2013; Stéfanon et al. 2014) and has been comprehensively evaluated in the literature (Hofstra et al. 2009, 2010; Kysel and Plavcov 2010; Flaounas et al. 2012; Herrera et al. 2012). In the E-OBS version 10 used here substantial improvements were realized, especially by increasing the station density (around 2000 for v1 and v2 vs. more than 4200 stations for temperature and more than 7300 for precipitation in v10). This should lead to some improvements in the drawbacks outlined above, and the E-OBS dataset is the only one that allows an RCM evaluation over the whole Mediterranean region.

\subsection{Observations: in-situ measurements}

Since the E-OBS product only provides daily values of temperature and precipitation we use in-situ measurements at subdaily time sampling for a better insight of the scaling of precipitation extreme with temperature (Utsumi et al. 2011; Drobinski et al. 2016). The in-situ data used in this work were collected at stations in Croatia, France, Israel, Italy, Spain and Greece. The locations of the stations are shown in Fig. 1 and additional details on the data are given in Table 1.

\subsection{Simulation set-up and models}

The list of regional climate models (RCMs) and details about the settings are given in Table 2. The simulations cover the ERA-Interim period 1989-2008 as initially recommended in MED-CORDEX project (Ruti et al. 2015). Some simulations were extended afterwards to cover the updated ERA-Interim period 1979-2008 and some reach 2014 in order to cover the HyMeX observation periods (Drobinski et al. 2014). All models use the 6-hourly ERA-Interim meteorological re-analysis as forcing data at the boundaries. For LMDZ, which is a global model with regional zoom capability, temperature, wind speed and

Table 1 Origin of the in-situ data, available time sampling, measurement period used in this work, data provider and references

\begin{tabular}{|c|c|c|c|c|c|}
\hline Country & $\begin{array}{l}\text { Number of } \\
\text { stations }\end{array}$ & Time sampling & $\begin{array}{l}\text { Measurement } \\
\text { period }\end{array}$ & Data provider & References \\
\hline Croatia & 1 & 1 and $3 \mathrm{~h}$, daily & 1995-2008 & DHMZ & Zaninovic et al. (2008) \\
\hline France & 1 & 3 h, daily & 1979-2008 & Météo-France & Drobinski et al. (2016) \\
\hline Greece & 1 & $3 \mathrm{~h}$, daily & 1978-2006 & HNMS & Mamara et al. (2013) \\
\hline Israel & 1 & 3 h, daily & 1950-2014 & IMS & - \\
\hline Italy & 1 & $3 \mathrm{~h}$, daily & 1985-2013 & MeteoTrentino & $\begin{array}{l}\text { Norbiato et al. (2009), Panziera et al. } \\
\text { (2015) and Zahumensky (2010) }\end{array}$ \\
\hline Spain & 1 & $\begin{array}{l}10,20 \text { and } 30 \mathrm{~min}, 1 \text { and } \\
3 \text { h, daily }\end{array}$ & $1957-2010$ & Ebro observatory & Segu (2003) and Turco et al. (2014) \\
\hline
\end{tabular}

All data provider are regional or national weather services except the Ebro Observatory 


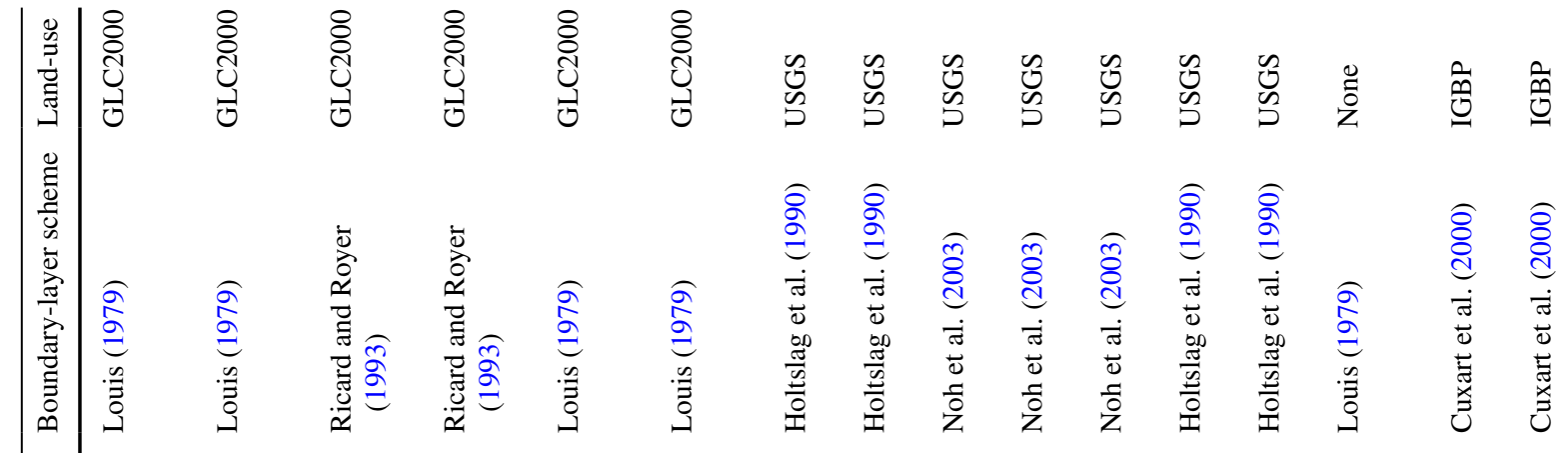

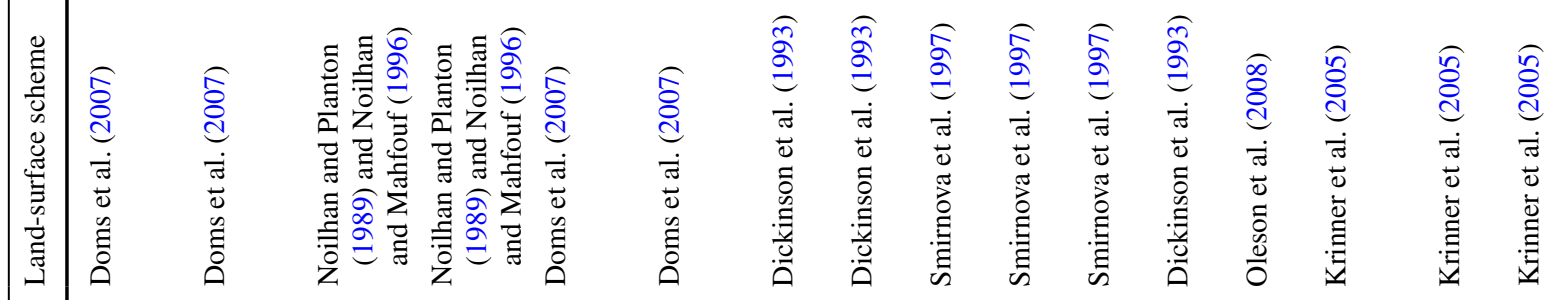

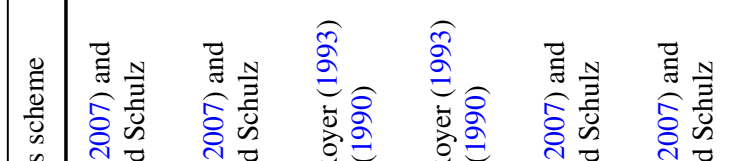

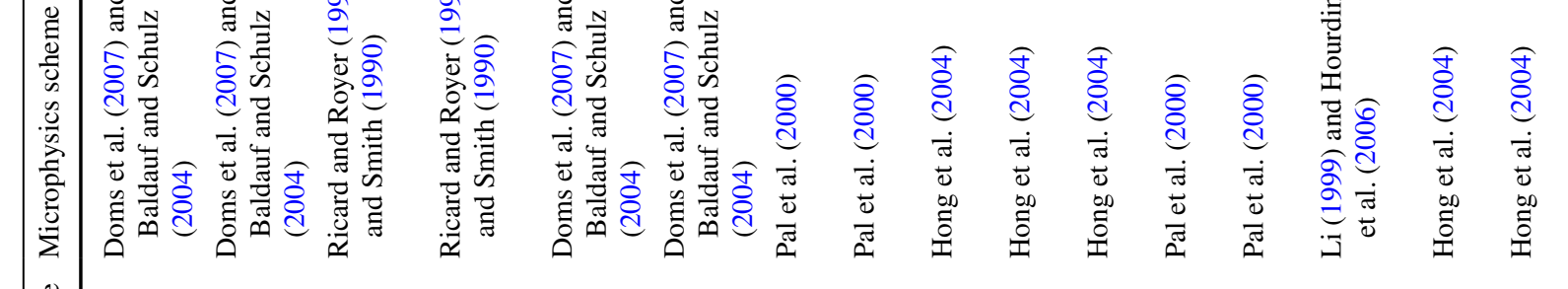

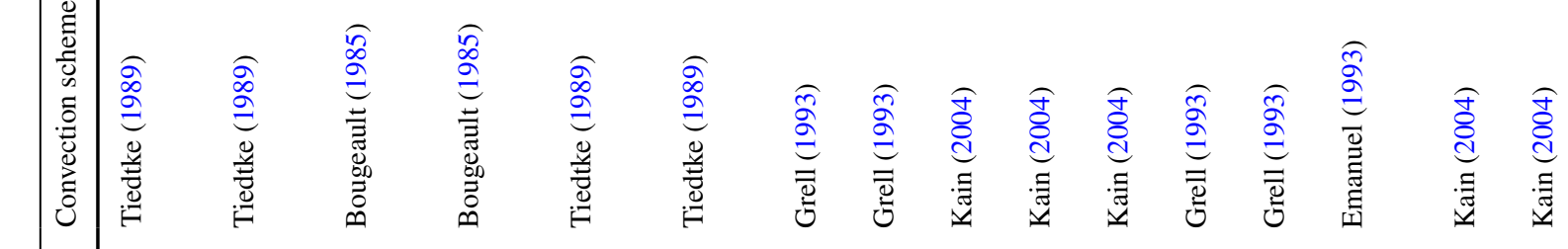

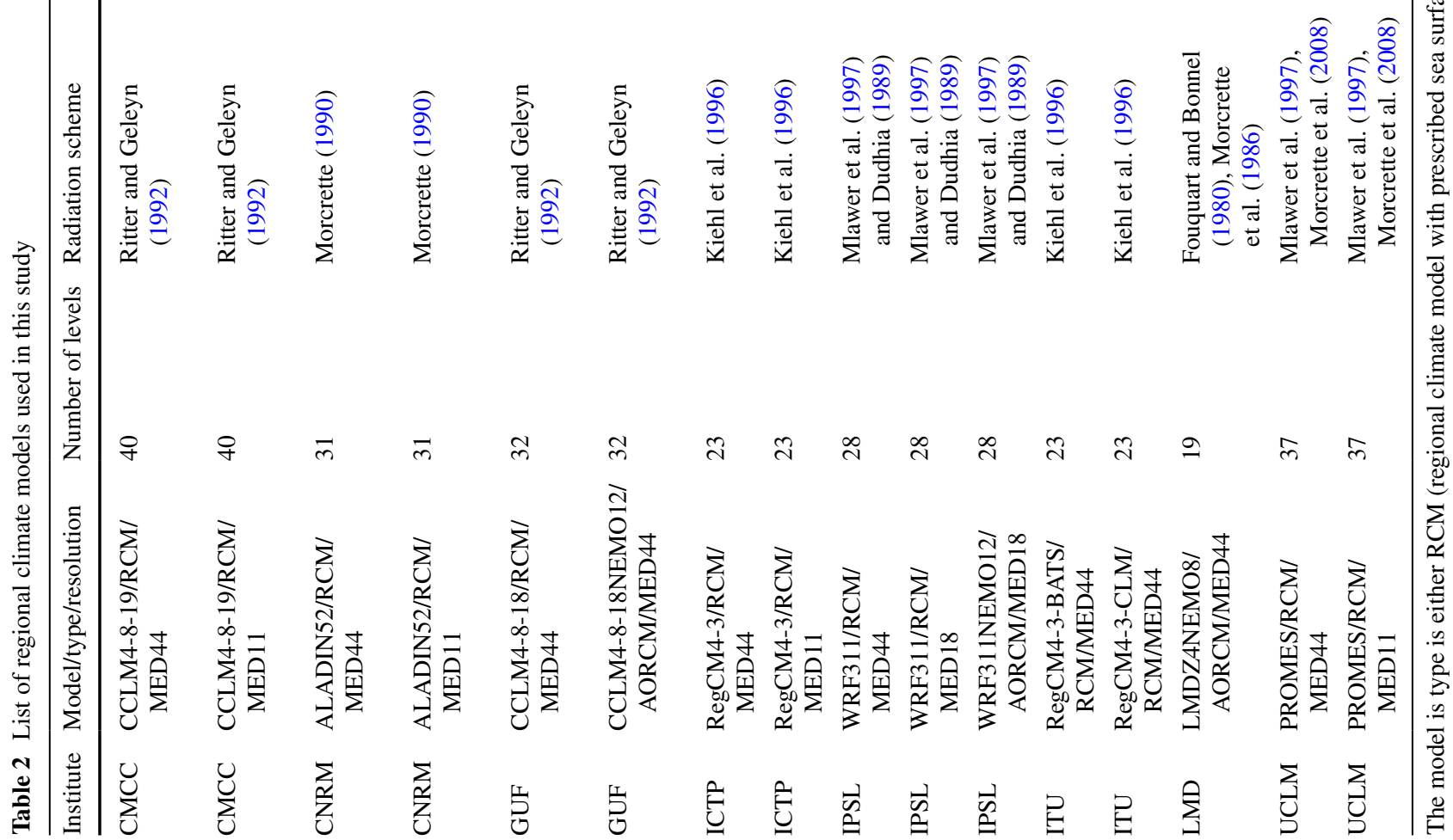


Table 3 Regional climate models versus global climate models matrix for the CMIP5 historical simulations and future climate projections (with RCP8.5 scenario)

\begin{tabular}{lllll}
\hline Regional models & \multicolumn{2}{l}{ Global models } & & \\
\cline { 2 - 4 } & CNRM-CM5 & HadGEM2-ES & IPSL-CM5A & MPI-ESM \\
\hline CNRM-ALADIN52 & $\times$ & & \\
ICTP-RegCM4-3 & & $\times$ & \\
ITU -RegCM4-3 (CLM and BATS) & & $\times$ & $\times$ \\
LMD-LMDZ4NEMOMED8 & & & \\
\hline
\end{tabular}

The crosses indicate the global model used to drive the regional model specific humidity are nudged towards the ERA-Interim fields outside the MED-CORDEX domain. It must be noted that the mesh is not regular within the zoom region and the resolution varies between 50 and $30 \mathrm{~km}$. All other limited area models are forced at the boundaries using 3-dimensional re-analyses of wind, humidity, temperature or potential temperature and geopotential height. For CCLM, cloud ice and liquid water are additionally prescribed at the domain boundaries. The IPSL WRF simulations use nudging at all scales within the domain for temperature, wind and humidity above the planetary boundary layer (Salameh et al. 2010; Omrani et al. 2013, 2015). The other models did not use nudging inside the inner domain.

For the downscaling of ERA-Interim reanalyses, 14 simulations were produced from eight models (ALADIN V5.2, Colin et al. 2010; Herrmann et al. 2011; CCLM, Rockel et al. 2008; RegCM V4.3, Giorgi et al. 2012; WRF V3.1.1, Skamarock et al. 2008; Drobinski et al. 2012 for the WRFNEMO-MED12 coupled system; LMDZ V4, Hourdin et al. 2006 coupled with NEMO-MED8). One of the novel aspects of MED-CORDEX is the use of high spatial resolution and atmosphere/ocean coupling, and one of the objectives of this article is to assess the sensitivity of the models' skill to ocean coupling and resolution. Five simulations were carried out with resolution higher than $50 \mathrm{~km}\left(0.11^{\circ}\right.$ or $\left.0.18^{\circ}\right)$, and nine with low resolution $\left(0.44^{\circ}\right)$ on the MED-CORDEX domain. Among these two sets, four simulations were made with the same model and similar setups (ALADIN, RegCM4, WRF) at high and low resolutions. Among the 14 simulations, 11 were run in atmosphere-only mode, i.e. at their lower boundary, sea surface temperatures were specified from the ERA-Interim reanalysis. Three runs include an interactive ocean model (using NEMOMED8 or NEMO-MED12, Lebeaupin Brossier et al. 2011, $2012 \mathrm{a}, \mathrm{b})$, with sea surface temperatures simulated by the coupled ocean model. In the following the simulations are referred to by the name of the modeling group followed by the name and version of the model and the resolution (11 for $0.11^{\circ}, 18$ for $0.18^{\circ}$ or 44 for $0.44^{\circ}$ ). The 3-hourly model outputs are used in the following.

The downscaling of the CMIP5 simulations are performed similarly to what is done for the ERA-Interim reanalyses downscaling. The global/regional model combinations are listed in Table 3. The high end RCP8.5 scenario is considered here, where RCP stands for Representative Concentration Pathways (IPCC 2013). The mean global warming projections for RCP8.5 by the CMIP5 models is $2.0{ }^{\circ} \mathrm{C}$ for $2046-2065$, with a likely range of $1.4-2.6^{\circ} \mathrm{C}$. It increases up to $3.7^{\circ} \mathrm{C}$ with a likely range of 2.6-4.8 ${ }^{\circ} \mathrm{C}$ at the 2081-2100 horizon.

\section{Assessment in the present climate}

\subsection{Observation analysis}

Figure 2 shows the 99th percentile of precipitation as a function of daily mean temperature at the surface weather stations in Croatia, France, Israel, Italy, Spain and Greece and from E-OBS at the nearest grid points for all available time sampling. Despite a dry bias of E-OBS with respect to the in-situ measurements, there is a remarkable agreement in the temperature-precipitation extremes relationship, and sub-CC scaling appears to be a common feature across the datasets for high temperatures. The first remarkable feature is that whatever the time sampling, all curves display a hook-shape as shown for France by Drobinski et al. (2016). We can define a temperature break below which the scaling is close to $\mathrm{CC}$, and above which the scaling is sub-CC with a quasi systematic negative slope. In other words, the temperature break corresponds to the temperature at which a sharp variation of the temperature-precipitation extreme slope occurs. The temperature break is around $20{ }^{\circ} \mathrm{C}$ in the west (Spain, France) and decreases when going eastwards with a temperature break around $7{ }^{\circ} \mathrm{C}$ in Greece. Despite some variability within each country, Fig. 3 shows that the general behaviour going from one country to the other is remarkably reproducible at all available stations. Figure 3 displays the temperature-precipitation extremes relationship at all selected stations in France, Italy, Israel and Greece (for Croatia and Spain, data from only one station is available). In Israel, the slope of the temperature-precipitation relationship is negative for all temperatures (e.g. Fig. 2c). None of the other Mediterranean stations exhibit such a trend for sub-daily timescales. This negative trend is found at several Israeli stations (Fig. 3c). A similar result 

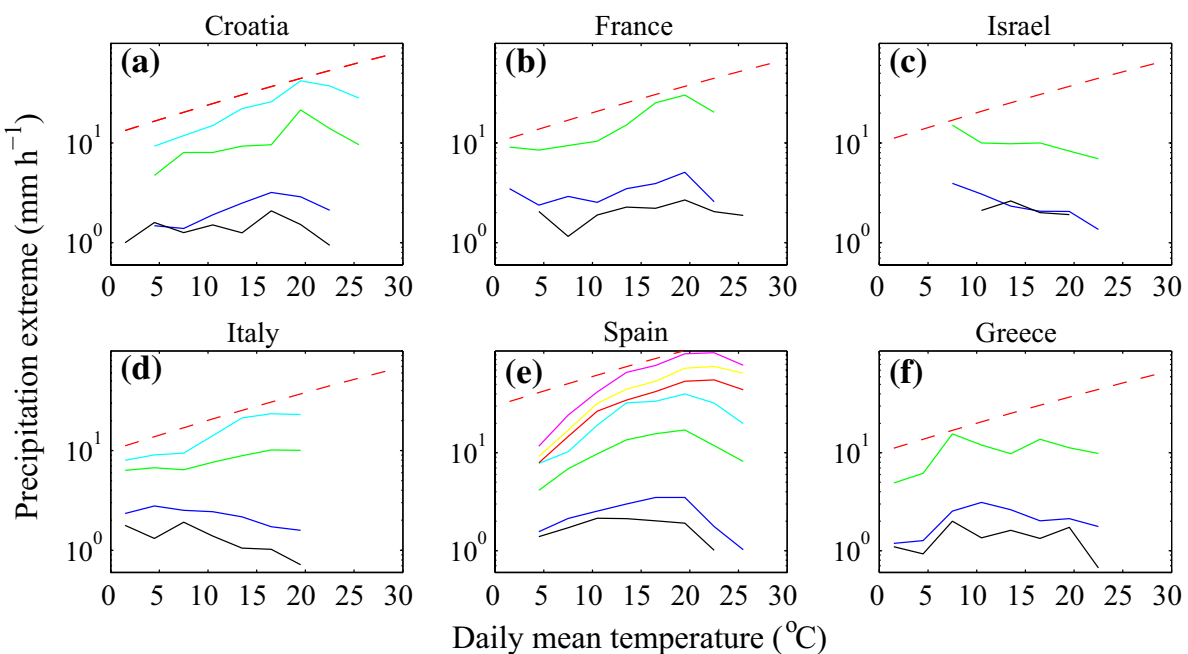

Fig. $210 \mathrm{~min}$ (magenta), $20 \mathrm{~min}$ (yellow), $30 \mathrm{~min}$ (red), hourly (cyan), 3-hourly (green) and daily (blue for in-situ and black for E-OBS) precipitation extremes (99th percentile) versus daily averaged temperature at the weather stations in Split in Croatia (a), near Montpellier in France (b), in Jerusalem in Israel (c), in Telve in Italy

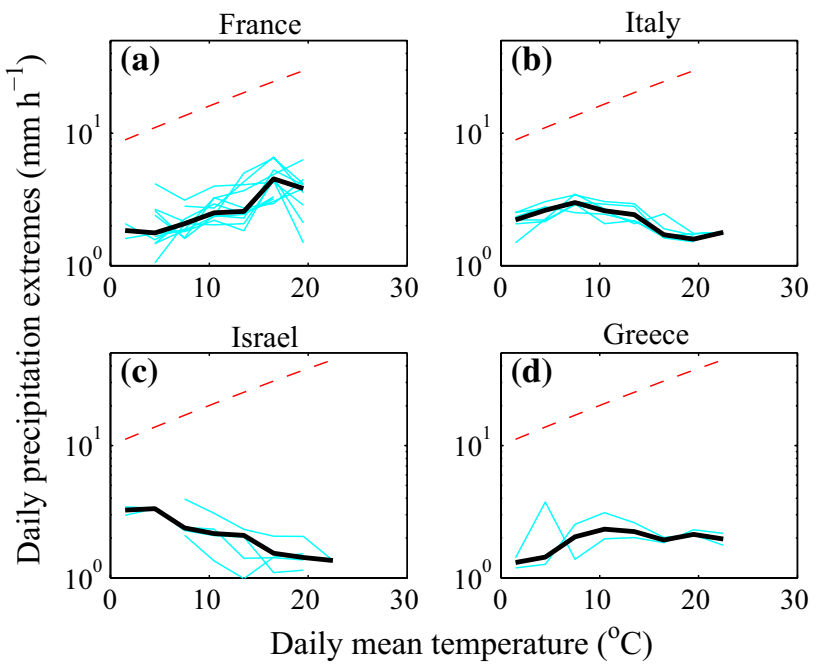

Fig. 3 Daily precipitation extremes (99th percentile) versus daily averaged temperature at all selected weather stations in France (a), Italy (b), Israel (c) and Greece (d) from the in-situ data (cyan). For each country, the relationship obtained by averaging all stations is displayed with a thick black line

was found in South-America tropical regions for daily precipitation extremes although sub-daily timescales were not investigated (Maeda et al. 2012).

As shown by Utsumi et al. (2011) in Japan and Drobinski et al. (2016) in southern France, the slope of the temperature-precipitation extremes relationship increases as time sampling decreases which can be well explained by the decrease in the duration of the precipitation events at high temperatures, and not by the decrease in the precipitation (d), in Roquetes in Spain (e) and in Alexandroupoli in Greece (f) from the in-situ data and the E-OBS data at the nearest grid point. Here and in the following figures, the dashed red line indicates the CC-slope using the August-Roche-Magnus approximation for saturated vapor pressure (Hardwick Jones et al. 2010)

intensity of individual storms. In Spain, the good quality of the dataset allows the evaluation of the time sampling limit below which the averaging effect is no longer affecting the slope. Since there is no significant differences between the slopes at high temperature for 30,20 and 10 min time sampling, one can conclude that the time sampling limit is between $30 \mathrm{~min}$ and $1 \mathrm{~h}$. In Spain, the sub-CC scaling at high temperatures is therefore real and not the result of time averaging. The fact that the hook-shape is also visible in Croatia for time sampling of $1 \mathrm{~h}$ suggests that such behaviour may be robust in this area, even though generalization must be considered with caution. In Spain, super$\mathrm{CC}$ is observed for the smallest timescales between 5 and $10{ }^{\circ} \mathrm{C}$.This is consistent with the observations of Lenderink and Meijgaard (2008) at De Bilt in Netherland, albeit super-CC scaling was found at much warmer temperatures, as also found in France for 3-hourly precipitation (Fig. 2b). This super-CC scaling was interpreted as resulting from a shift in rain type by Haerter and Berg (2009), and Berg and Haerter (2013), though the first reference is a hypothesis, whereas the second only discusses a small number of stations. Berg et al. (2013) and Loriaux et al. (2013) found with smaller statistical effect a super-CC scaling with convective precipitation only, the latter showing an important role of the vertical velocity for super-CC behavior.

\subsection{Simulation evaluation and analysis}

Figure 4 shows the daily precipitation 99 th percentile as a function of daily mean temperature at the surface weather stations in Croatia, France, Israel, Italy, Spain and Greece 
and from the HyMeX/MED-CORDEX simulations at the nearest grid point. Analysis of the temperature-precipitation extreme curves in Figs. 2 and 4 shows that the temperature break decreases from west to east. It is around 16-20 ${ }^{\circ} \mathrm{C}$ in France, Croatia and Spain, it goes down to around $7-10{ }^{\circ} \mathrm{C}$ in Greece and it is no longer detectable in Israel where the slope is always negative. The models display a very similar scaling, with an accurate representation of the slopes and temperature breaks, despite a systematic underestimation of the precipitation extremes which is expected when comparing local precipitation with area averaged precipitation over a grid of about $2500 \mathrm{~km}^{2}$ (Chen and Knutson 2008). The GUF-CCLM4-8-18-MED44 simulation is the closest to the observed amount of precipitation extreme (as measured by the 99th percentile) while the CNRM-ALADIN52-MED44 simulation always produces much lower extremes than observed. Besides the averaging effect, sub-CC scaling may also be attributed, to aridity which may limit the rainfall amount as suggested by Hardwick Jones et al. (2010) for Central Australia stations. In the northwestern Mediterranean, Drobinski et al. (2016) also attribute the sub-CC scaling to the arid environment with three consequences. First, the 2-m temperature is no longer a proxy of the temperature of the condensed parcel, as precipitation is produced at much higher altitudes due to higher condensation levels. The surface temperature is thus much higher than the temperature of the condensed parcel. Second, the relatively dry air surrounding the precipitating system reduces the precipitation efficiency which thus reduces the slope of the temperature-precipitation extremes relationship. Third, the entrainment of relatively dry unsaturated environmental air dilutes the rising saturated air parcels and causes evaporative cooling, which in turn reduces the buoyancy of the convective parcel and the vertical transport of humidity. These processes reduce the slope of the temperature-precipitation extremes relationship and cause the reduction in temperature break as conditions become drier from Spain to Israel along the coast. Note that the Italian stations do not exhibit a clear temperature break. These stations are located in the mountains at high altitudes (Fig. 1), and as will be shown in Fig. 13, at those altitudes aridity conditions do not occur often and do not limit the rainfall amounts.

The scalings of precipitation extremes in Italy and Israel display a negative slope above about $10^{\circ} \mathrm{C}$, which is fairly well reproduced by all simulations except CMCC-CCLM48-19-MED44 and GUF-CCLM4-8-18-MED44. However, contrary to Israel, the slope of the temperature-precipitation extreme curves in Italy is sensitive to time sampling as CC-scaling is found for hourly precipitation extremes (Fig. 2d).

Figure 5 shows the spatial pattern of the slope of the temperature-precipitation extremes relationship for temperatures lower than the temperature break or in the absence of temperature break. The slope at low temperatures is close to the CC-scaling $\left(\sim 7 \%{ }^{\circ} \mathrm{C}^{-1}\right)$ for most of the northwestern regions. Negative slopes are observed in the south and east of the Mediterranean basin. All models reproduce fairly accurately the limit between the regions with nearly $\mathrm{CC}$-scaling and those with sub-CC scaling, which indicates
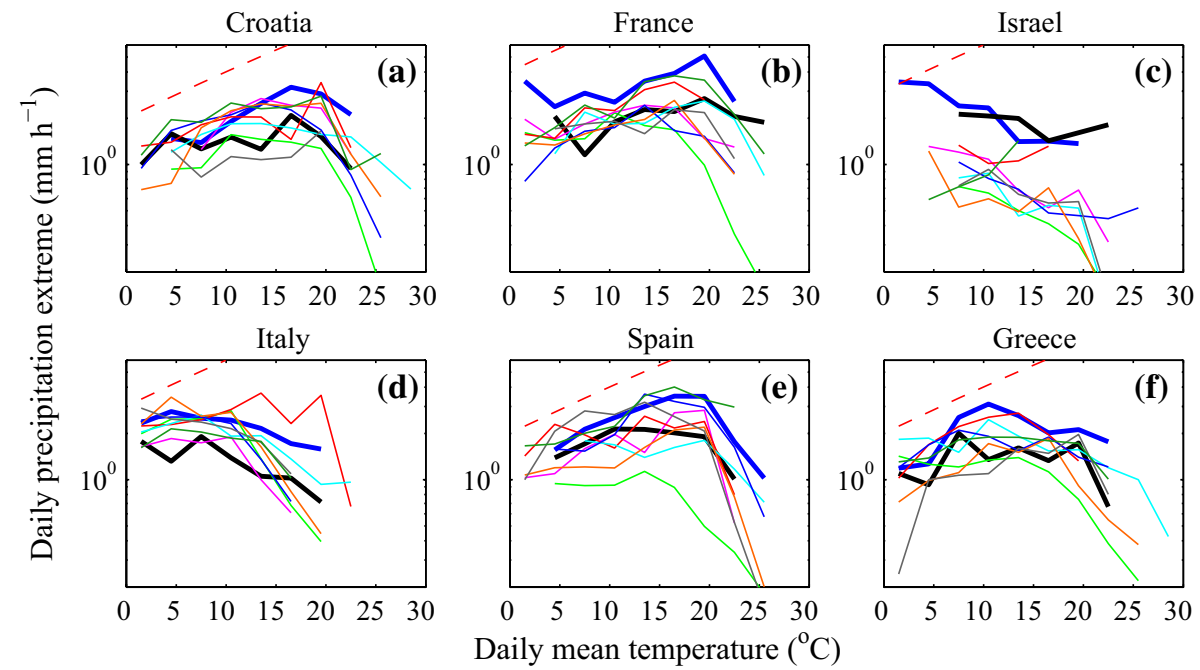

Fig. 4 Daily precipitation extremes (99th percentile) versus daily averaged temperature at the weather stations in Split in Croatia (a), coastal plain in France (b), in Jerusalem in Israel (c), in Telve in Italy (d), in Roquetes in Spain (e) and in Alexandroupoli in Greece (f) from the in-situ data (thick blue line), the E-OBS data at the nearest grid point (thick black line) and from HyMeX/MED-CORDEX simulations at $0.44^{\circ}$ resolution (CMCC-CCLM4-8-19-MED44: red; CNRM-ALADIN52-MED44: green; ICTP-RegCM4-3-MED44: orange; ITU-RegCM4-3-CLM-MED44: magenta; IPSL-WRF311MED44: cyan; GUF-CCLM4-8-18-MED44: dark green; UCLMPROMES-MED44: grey; LMD-LMDZ4NEMOMED8-MED44: blue) at the nearest grid point 

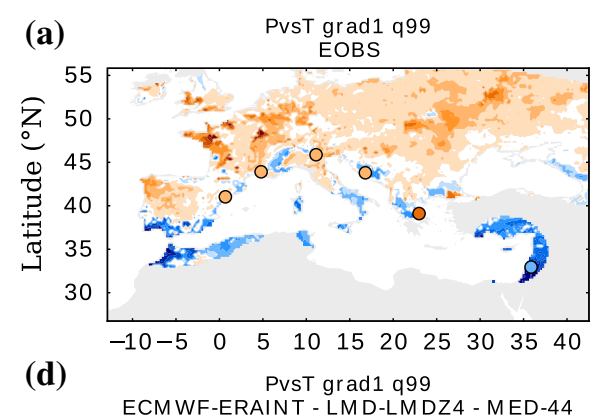

PVsT grad1 q99
(b) ECMWF-ERAINT - IPSL-WRF311 - MED-44
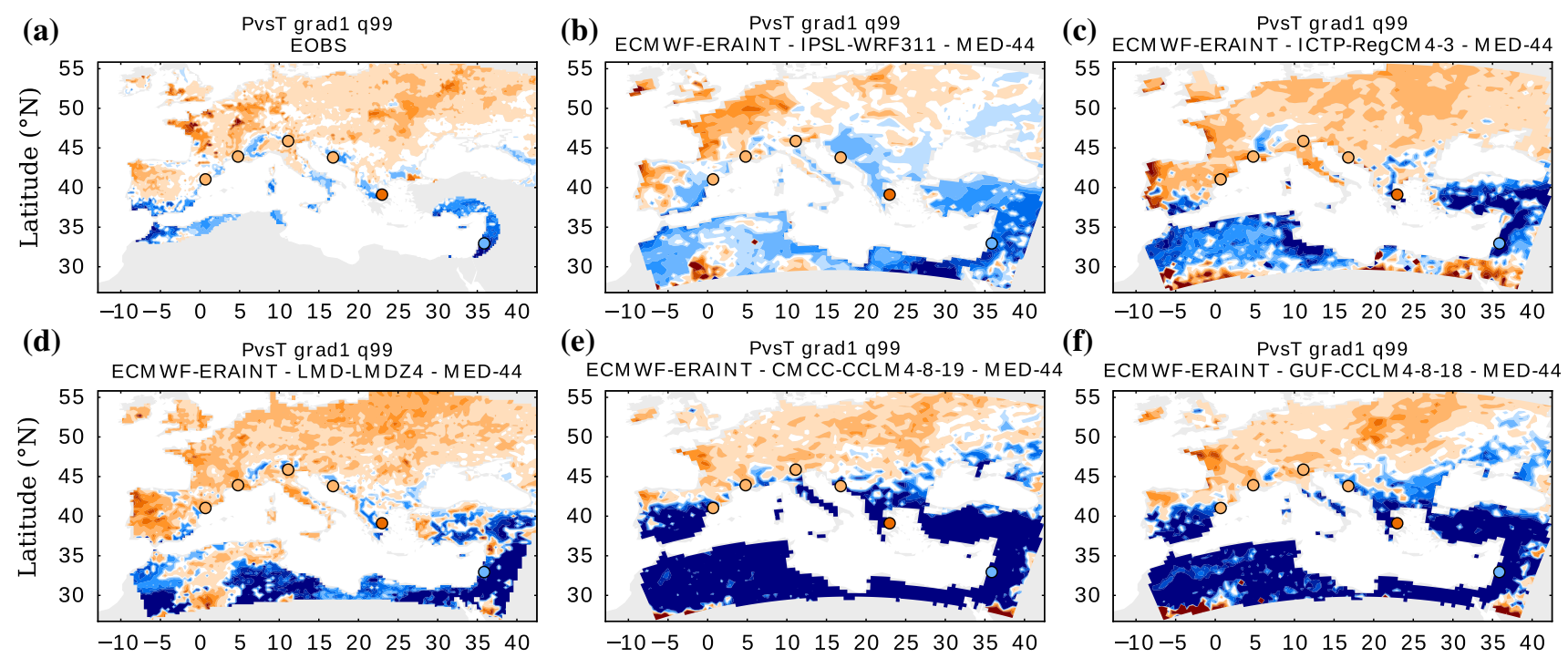

PVsT grad1 q99
ECM WF-ERAINT - UCLM -PROMES - MED-44

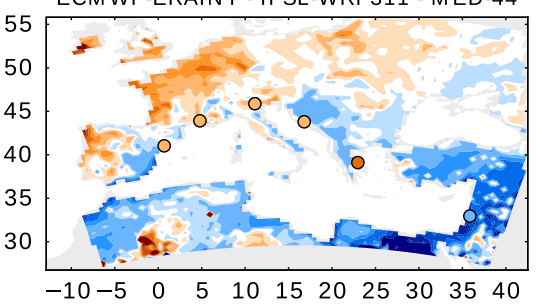

(e)

PvsT grad1 q99

(f)

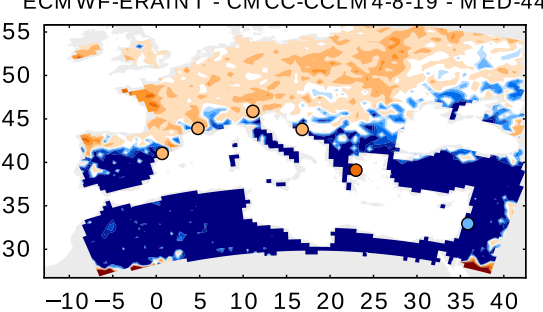

ECM WF-ERAINT - GUF-CCLM 4-8-18 - MED-44

PvsT grad1 q99
(h)

PvsT grad1 q99
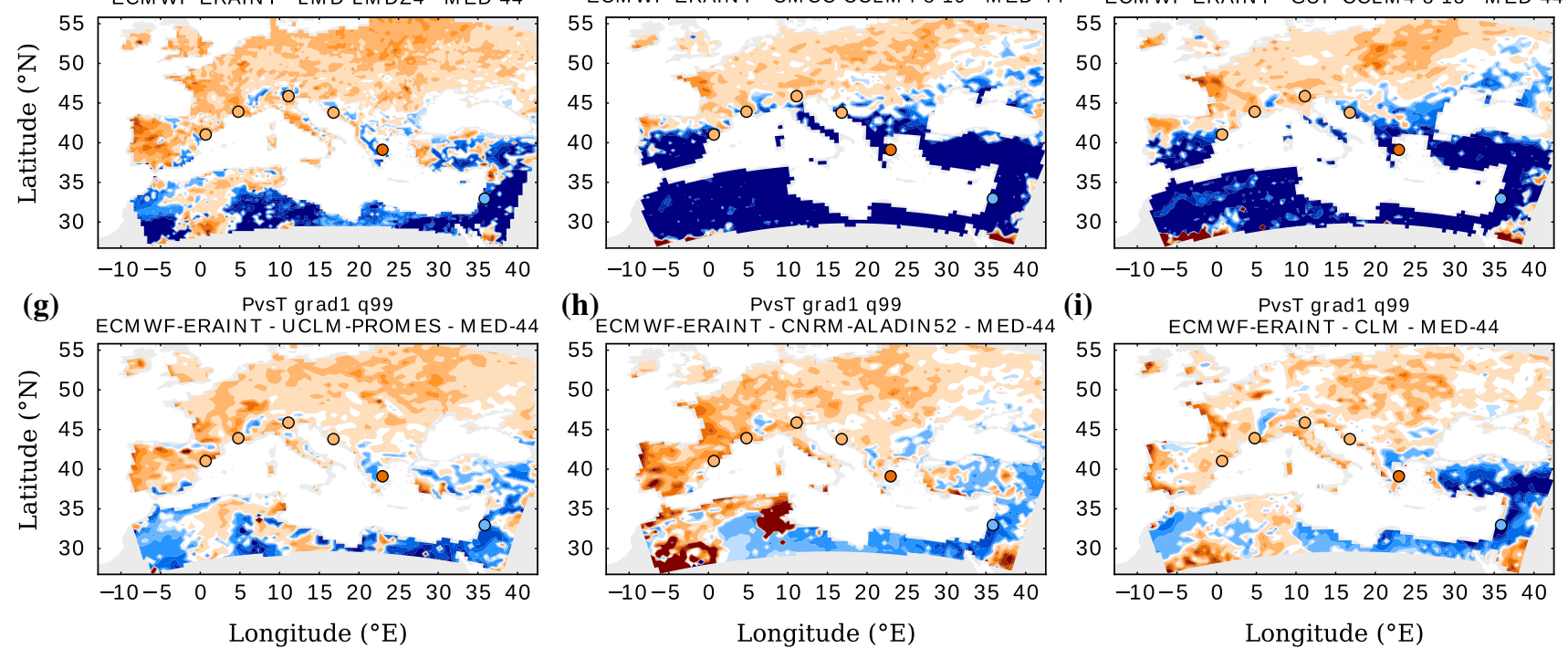

(i)

PvsT grad1 q99

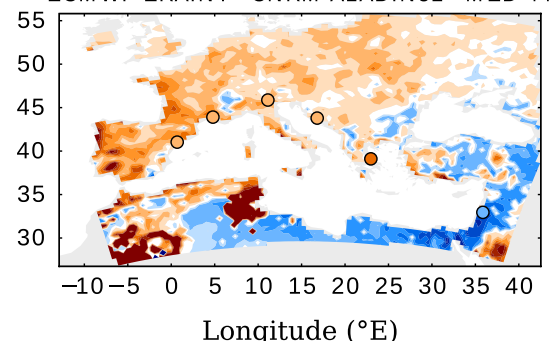

ECMWF-ERAINT - CLM - MED-44

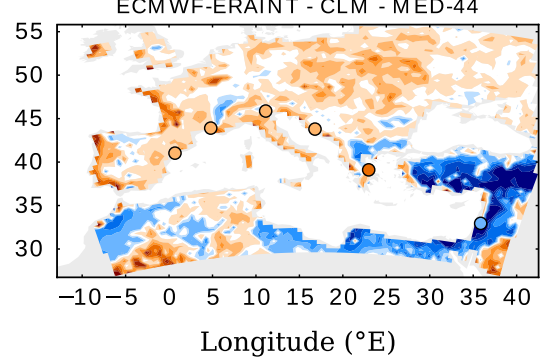

Longitude $\left({ }^{\circ} \mathrm{E}\right)$

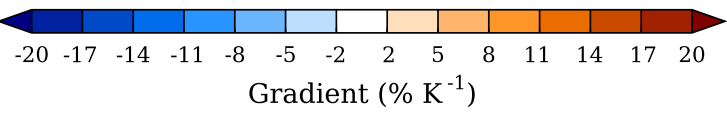

Fig. 5 Slope of the temperature-precipitation extremes relationship for a range of temperatures colder than the temperature break derived from E-OBS dataset and from the HyMeX/MED-CORDEX simula-

the limit of arid Mediterranean regions. Some simulations produce a too steep negative slope, such as ICTP-RegCM43-MED44, LMD-LMDZ4NEMOMED8-MED44, CMCCCCLM4-8-19-MED44, and GUF-CCLM4-8-18-MED44, while others underestimate (CNRM-ALADIN52-MED44) or overestimate (IPSL-WRF311-MED44) the area of arid conditions with negative slope in the northern Mediterranean. However, the largest differences across models are found where there are no available E-OBS measurements. Figure 6 displays the spatial pattern of the slope of the temperature-precipitation extremes relationship for temperatures higher than the temperature break. No slope is found in most parts of the eastern and southern Mediterranean, where no temperature break could be estimated (Fig. 5). Negative slope, i.e. sub-CC-scaling, is found everywhere in the Mediterranean in the E-OBS dataset and in the simulations. Sub-CC scaling is found above a temperature mostly ranging between 27 and $3{ }^{\circ} \mathrm{C}$ from west to east (Fig. 4), tions at $0.44^{\circ}$ horizontal resolution. The coloured dots indicate the value of the slope at the various sites in Croatia, France, Greece,Italy, Israel and Spain

to be compared to a value of $\sim 20-25{ }^{\circ} \mathrm{C}$ in some previous studies (e.g. Utsumi et al. 2011).

As for the daily time sampling, models systematically underestimate the 3-hourly precipitation intensity as shown in Fig. 7. For the Israeli station, the observed temperatureprecipitation extreme curve is too variable so that no conclusion can be drawn. All models still produce a negative slope at all temperatures, except the CNRM-ALADIN52MED44 simulation which shows a hook shape curve with a temperature break around $10{ }^{\circ} \mathrm{C}$. CMCC-CCLM4-8-19MED44 and GUF-CCLM4-8-18-MED44 simulations display a slightly positive slope. At all other stations except the French ones, all models produce a flattening of the negative slope at high temperatures. In Italy, the slope retrieved from the in-situ data is positive for temperatures higher than the temperature break, whereas it is still negative in all models. In France, the scaling of precipitation extremes with temperature is better reproduced by all models. 


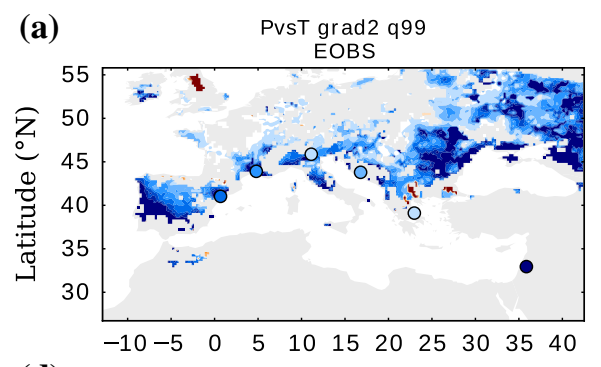

(d)

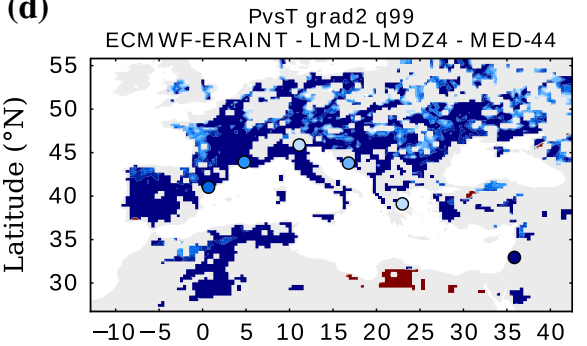

(g)

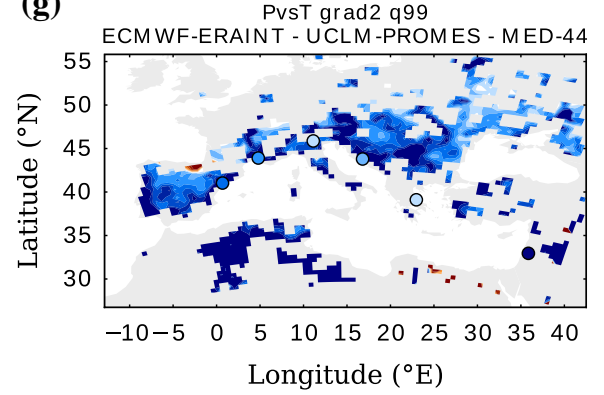

(b) Pvst grad2 q99

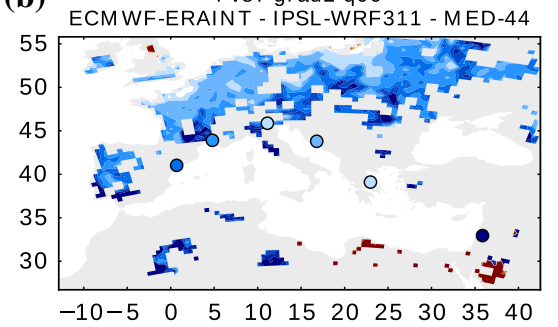

(e)

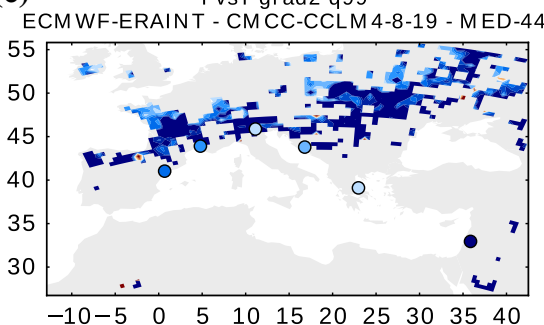

(h)

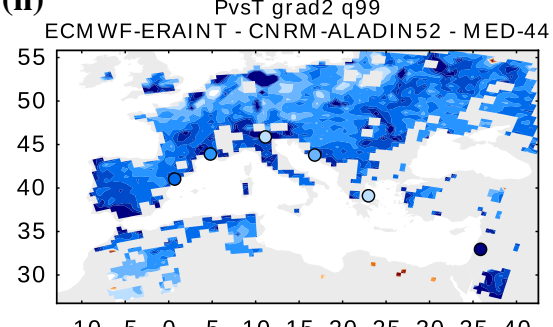

$\begin{array}{llllllllll}-10-5 & 0 & 5 & 10 & 15 & 20 & 25 & 30 & 35 & 40\end{array}$ Longitude $\left({ }^{\circ} \mathrm{E}\right)$ (c) PvsT grad2 q99

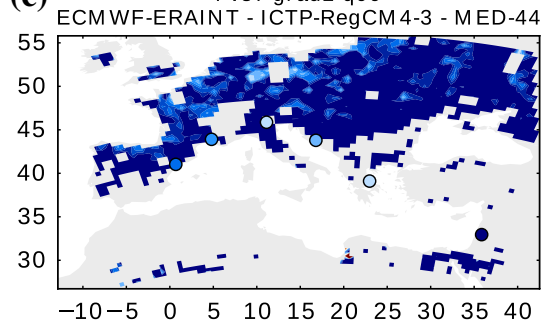

(f)

PvsT grad2 q99

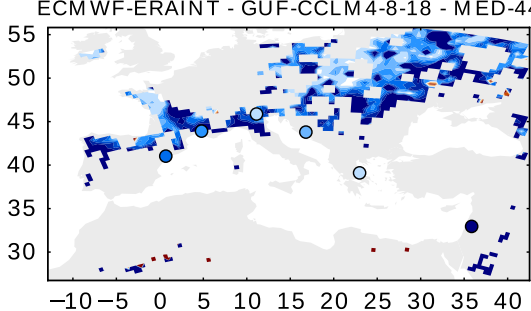

(i)

PvsT grad2 q99

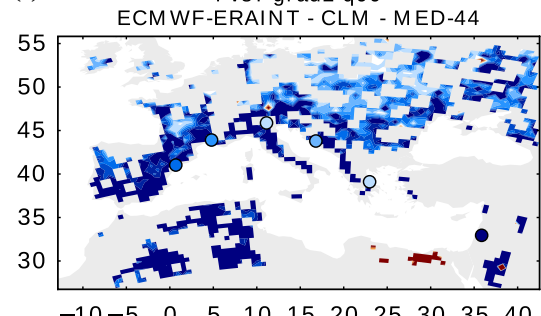

Longitude $\left({ }^{\circ} \mathrm{E}\right)$

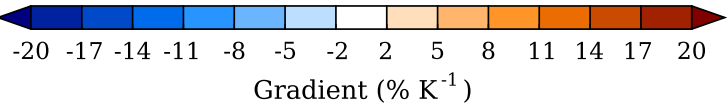

Fig. 6 Similar to Fig. 5 for a range of temperatures warmer than the temperature break

Fig. 7 Same as (Fig. 4) for 3-hourly precipitation data
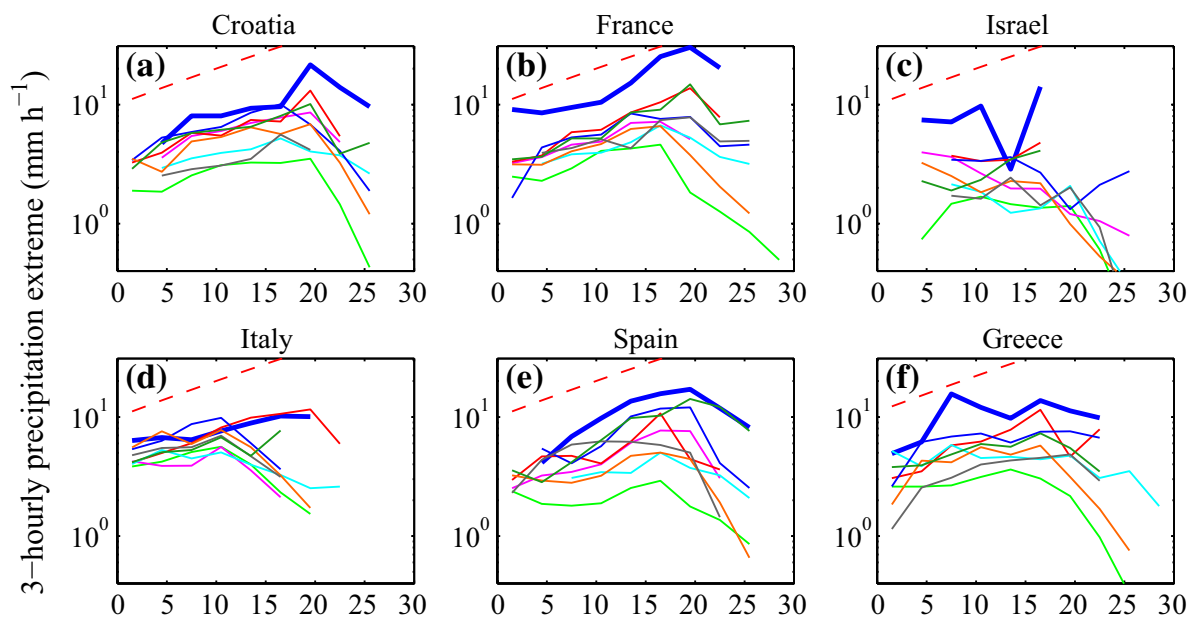

Daily mean temperature $\left({ }^{\circ} \mathrm{C}\right)$
Our analysis shows that there is no effect of the horizontal resolution $(0.44-0.11)$ on the scaling of precipitation extremes for daily precipitation (not shown). When 3-hourly precipitation data are used, the sensitivity to the horizontal resolution becomes more significant at some stations, even though the effect is small. Indeed, the ratio of 3-hourly to daily precipitation extremes, which measures the duration of the simulated events (e.g. Utsumi et al. 
2011; Drobinski et al. 2016), appears to be sensitive to the resolution at high temperatures. The ratio equals 1 when the daily averaged precipitation reduced over a period of three hours (i.e. divided by 8 ) is equal to the 3-hourly accumulated precipitation. This essentially means that it rains throughout the day. Conversely, when the ratio equals 8 , it only rains during $3 \mathrm{~h}$ during the day. At low temperatures, the ratio is statistically the same between the simulations performed at high and low resolutions, with a value of about 2.5 in good agreement with the observations (not shown). This ratio is quite low, suggesting long-lasting simulated extreme precipitation events probably dominated by non-convective precipitation. The ratio increases with temperature for both simulations and weather station measurements, but with a lower rate for the low-resolution experiments. At the highest temperatures, the difference of ratio between the high and low resolution experiments is generally significant except for UCLM-PROMES. The ratios from the high-resolution simulations are lower, but closer to observations $(\simeq 6)$, than low-resolution models. However, the spread across models increases with temperature (not shown). At high temperatures, the simulated precipitation extremes are mainly of convective nature and their duration is highly sensitive to the convection scheme. The rate at which the ratio increases with temperature is larger for the simulations performed at high than low resolution, and therefore, going from daily (Fig. 4) to 3-hourly (Fig. 7) precipitation extremes, the high resolution runs straighten the temperature-precipitation extreme curve at high temperatures more than the low resolution ones.

Regarding ocean-atmosphere feedbacks, no sensitivity to the atmosphere-ocean coupling was found on the scaling of precipitation extremes with temperature (not shown). This is not surprising, since atmosphere-ocean feedbacks affect predominantly the location of the precipitating event rather than the intensity (Lebeaupin-Brossier et al. 2013, 2015; Berthou et al. 2014, 2015).

\section{Projections in the future climate}

\subsection{Comparison between historical and ERA-Interim simulations}

Before investigating climate change effects, we investigate the ability of historical runs to reproduce ERA-Interim results. Figure 8 shows the daily precipitation extremes as a function of the daily mean temperature at the 6 weather stations and in the HyMeX/MED-CORDEX simulations (CNRM-ALADIN52-MED44, ITU-RegCM4-3-BATSMED44, ITU-RegCM4-3-CLM-MED44, ICTP-RegCM43-MED44, LMD-LMDZ4NEMO8-MED44) forced by ERA-Interim reanalysis and by the historical CMIP5 GCM simulations (Table 3). For all stations and precipitation accumulation duration, there is a good agreement between the ERA-Interim and CMIP5 downscaled simulations over the 1979-2005 period (or 1989-2005 for some models; Table 2). Temperature breaks can slightly differ, but these differences are generally not significant and are caused by the different ranges of the temperature bins used to compute the temperature-precipitation extreme relationship. The largest differences between the scalings of precipitation extremes computed from the ERA-Interim and CMIP5 downscaled simulations are found for CNRM-ALADIN52MED44, where the slope at high temperature is generally steeper in the ERA-Interim downscaled simulations. One can note a general underestimation of the ICTP-RegCM4 precipitation intensity at low temperatures which leads to an overestimation of the slope at these temperatures.

\subsection{Projection in the future climate}

Figure 9 shows the daily precipitation extremes as a function of the daily mean temperature at the 6 weather stations and for the GCM-driven HyMeX/MED-CORDEX simulations for the historical period (1979-2005) and the future period 2070-2100. The most striking changes are (1) an increase of the temperature break by about $4-5{ }^{\circ} \mathrm{C}$ and therefore a broader temperature range over which the slope is close to the CC-scaling; (2) a change in the value of the sub-CC slope at high temperatures, with steeper or flatter slopes depending on the model. The latter effect is even more pronounced when analyzing the 3-hourly model outputs (not shown). Such evolution of the scaling of precipitation extremes with temperature suggests that a simple CC-scaling may not be used as a predictor.

From a simple CC-scaling argument, if all other aspects of convection remain unchanged with warming (in particular precipitation efficiency or vertical updraft velocities, Drobinski et al. 2016), one would expect a simple shift of the precipitation extremes curve parallel to the CC slope towards higher temperatures (Fig. 10). Indeed, if all other aspects of convection remain constant, the simple thermodynamic expectation is that precipitation extremes should scale with the humidity convergence at cloud base, i.e. $P_{\text {extreme }} \propto R H Q_{\text {sat }}$ (Betts and Harshvardhan 1987; O'Gorman and Schneider 2009), where $P_{\text {extreme }}$ denotes an extreme rainfall rate, $Q_{\text {sat }}$ is the low-tropospheric saturation specific humidity, and $R H$ is the low-tropospheric relative humidity. If $R H$ stays constant in time with warming, and if the temperature increase is uniform in space, then the temperature increase only impacts precipitation extremes through the contribution from $Q_{\text {sat }}$. The latter follows CCscaling (Fig. 10).

The temperature break shifts towards higher temperatures by about $4-5{ }^{\circ} \mathrm{C}$ over the whole Mediterranean region 
Fig. 8 Daily precipitation extremes (99th percentile) versus daily averaged temperature at nearest grid point from the weather stations from the HyMeX/MED-CORDEX simulations at $0.44^{\circ}$ resolution (CNRM-ALADIN52-MED44: green; ITU-RegCM4CLM3-MED44: magenta; ITURegCM4BATS-3-MED44: black; ICTP-RegCM4-3MED44: orange; LMDLMDZ4NEMOMED8-MED44: blue) driven by the ERAInterim reanalysis (left column) and the CMIP5 historical simulations performed by the GCM of Table 3 (right column)
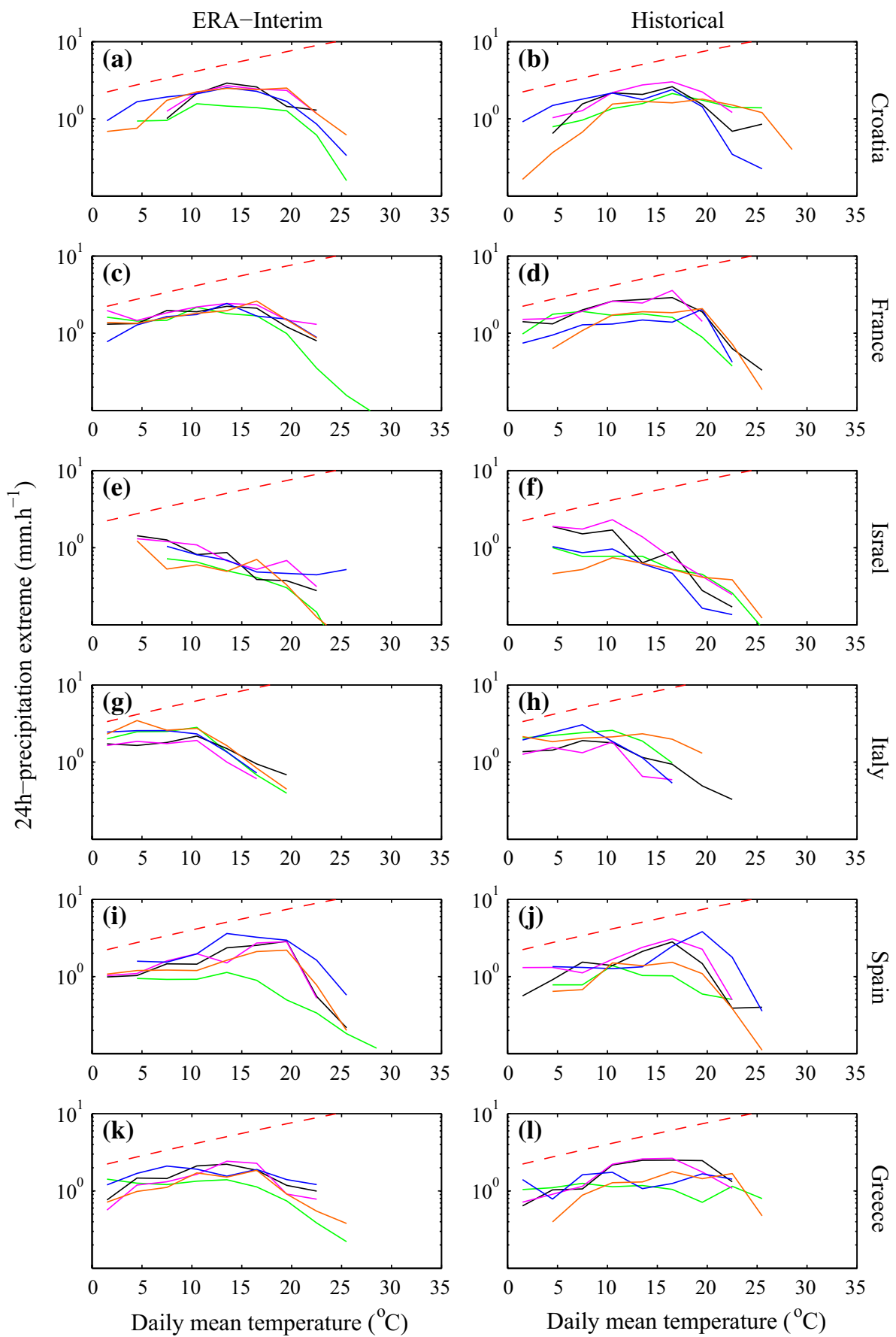

and Europe (including Eastern Europe) for all models without much spread across models (not shown). The value of the temperature break shift corresponds to the average temperature change in the region $\left(3-4{ }^{\circ} \mathrm{C}\right)$, which is one of the highest warming rates in the world both in observations (e.g. Quereda Sala et al. 2000; Xoplaki et al. 2003; Solomon et al. 2007) and in the scenario projections (e.g. Giorgi 2006). However, a simple temperature translation by $4-5{ }^{\circ} \mathrm{C}$ of the temperature-precipitation extreme curve obtained from the historical runs does not allow the reconstruction of the curve obtained from the downscaled RCP8.5 simulations, since such translation would not reproduce the change of the slope at high temperatures (Fig. 10).

Figure 11 shows the warming between historical and future daily mean temperatures for rainy days at the nearest grid point to the weather stations from the HyMeX/ MED-CORDEX simulations at $0.44^{\circ}$ resolution. The average shift of the temperature break corresponds approximately to the average temperature difference simulated 
Fig. 9 Daily precipitation extremes (99th percentile) versus daily averaged future temperature at nearest grid point from the weather stations from the HyMeX/MED-CORDEX simulations at $0.44^{\circ}$ resolution (CNRM-ALADIN52-MED44: green; ITU-RegCM4BATS3-MED44: black; ITU-RegCM4CLM-3-MED44: magenta; ICTP-RegCM4-3-MED44: orange; LMD-LMDZ4NEMO8MED44: blue) driven by the CMIP5 historical simulations and RCP8.5 scenarios performed by the GCM of Table 3 for the historical (left column) and 2070-2100 (right column) periods
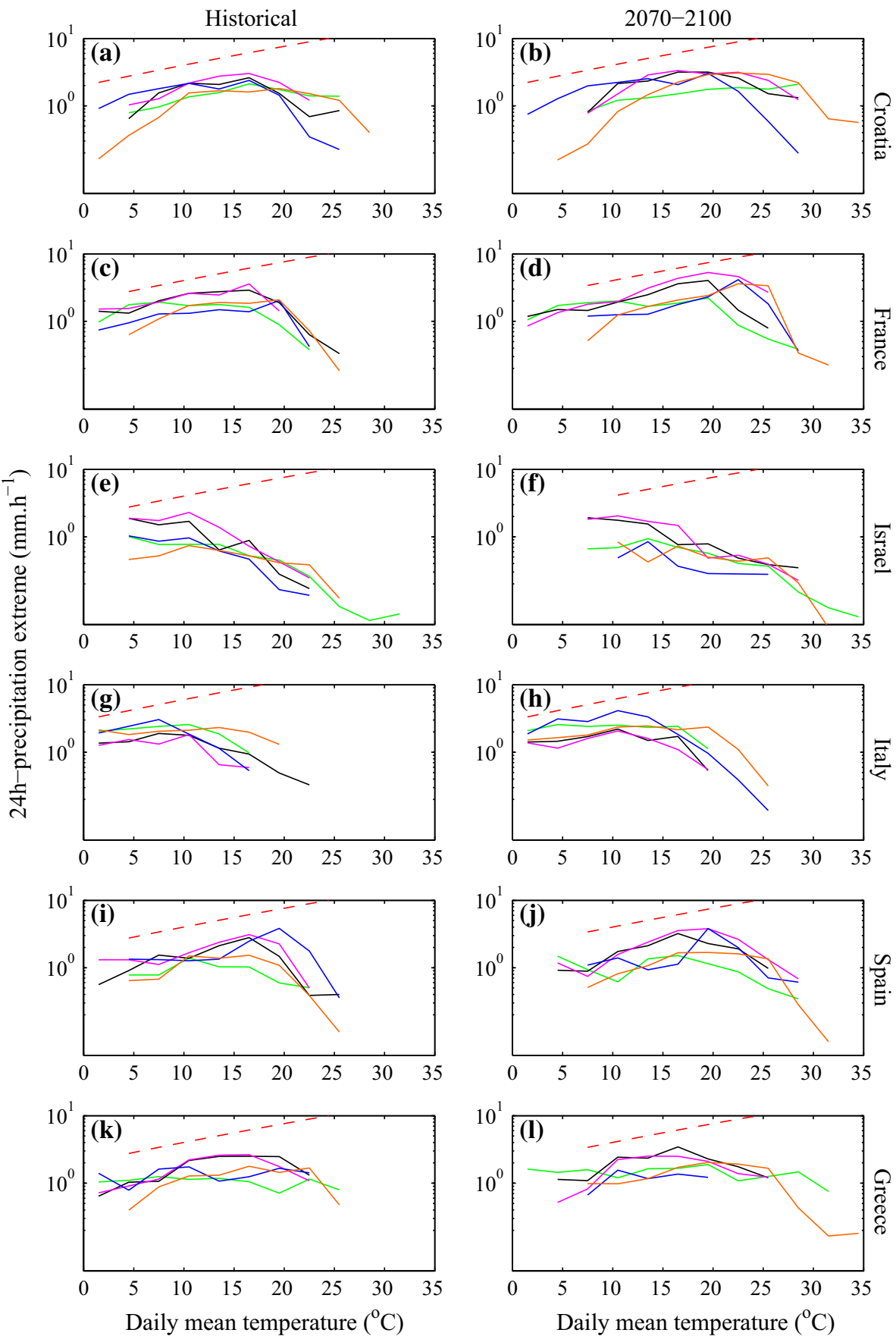

between 2070-2100 and 1979-2005. In France for instance, ICTP-RegCM4-3-MED44 shifts the temperature break from 20 to $25{ }^{\circ} \mathrm{C}$ (Fig. 9d), which also corresponds to the mean temperature change at $25{ }^{\circ} \mathrm{C}$ (Fig. 11). Although models produce very similar results for the scaling of precipitation extremes with temperature, the warming relationships in Fig. 11 are characterized by a large spread across models. For instance, in Croatia, all models exhibit temperature warming curves with a "U-shape", but in Greece, the temperature change decreases with temperature for
LMD-LMDZ4NEMO8-MED44, it has a "U-shape" for ITURegCM4CLM-3-MED44, ITU-RegCM4CLM-3-MED44 and ICTP-RegCM4-3-MED44 and a more irregular shape for CNRM-ALADIN52-MED44.

The fact that the warming $T^{\prime}-T$ is not the same at all temperatures $T$, where $T$ and $T^{\prime}$ denote current and future climate temperatures respectively, can change the thermodynamic expectation described in Fig. 10. The temperature-precipitation extreme curves obtained from the historical simulations adjusted assuming the CC-scaling with 


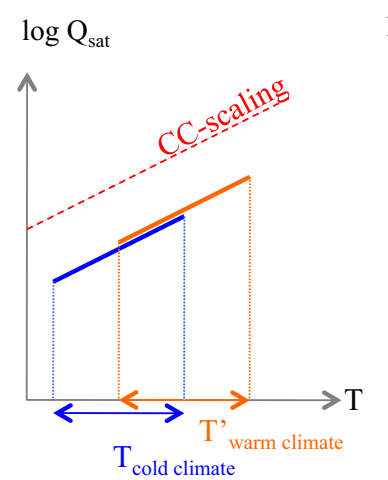

$\log \mathrm{RH}$

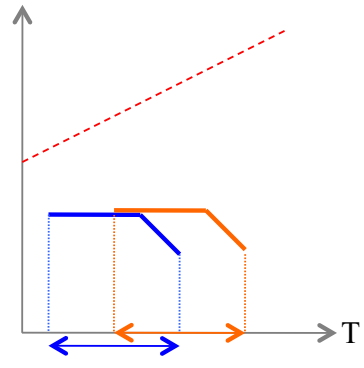

$\log \mathrm{P}_{\text {extreme }}$

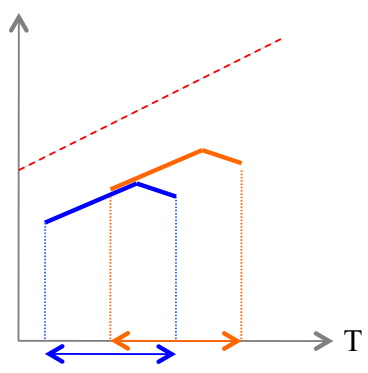

Fig. 10 Schematic representation of the expected change of the scaling of precipitation extremes with warming (right panel). $T$ and $T^{\prime}$ denote current and future climate temperatures respectively. If all other aspects of convection remain constant, the simple thermodynamic expectation is that precipitation extremes should scale with the humidity convergence at cloud base, i.e. $P_{\text {extreme }} \propto R H Q_{\text {sat }}$. The relative humidity $R H$ is assumed to remain constant at each location (middle panel) but simply shifts to warmer temperatures as each location warms. The temperature increase $T^{\prime}-T$ is assumed to be the same at all locations. In that case precipitation extremes increase with warming only through an increase in the low-tropospheric saturation specific humidity $Q_{\text {sat }}$, which follows CC-scaling (left panel)
Fig. 11 Difference between historical and future daily mean temperature of rainy days at nearest grid point from the weather stations from the HyMeX/MED-CORDEX simulations at $0.44^{\circ}$ resolution (CNRM-ALADIN52-MED44: green; ITU-RegCM4BATS3-MED44: black; ITU-RegCM4CLM-3-MED44: magenta; ICTP-RegCM4-3-MED44: orange; LMD-LMDZ4NEMO8MED44: blue) driven by the CMIP5 historical simulations and RCP8.5 scenarios performed by the GCM of Table 3
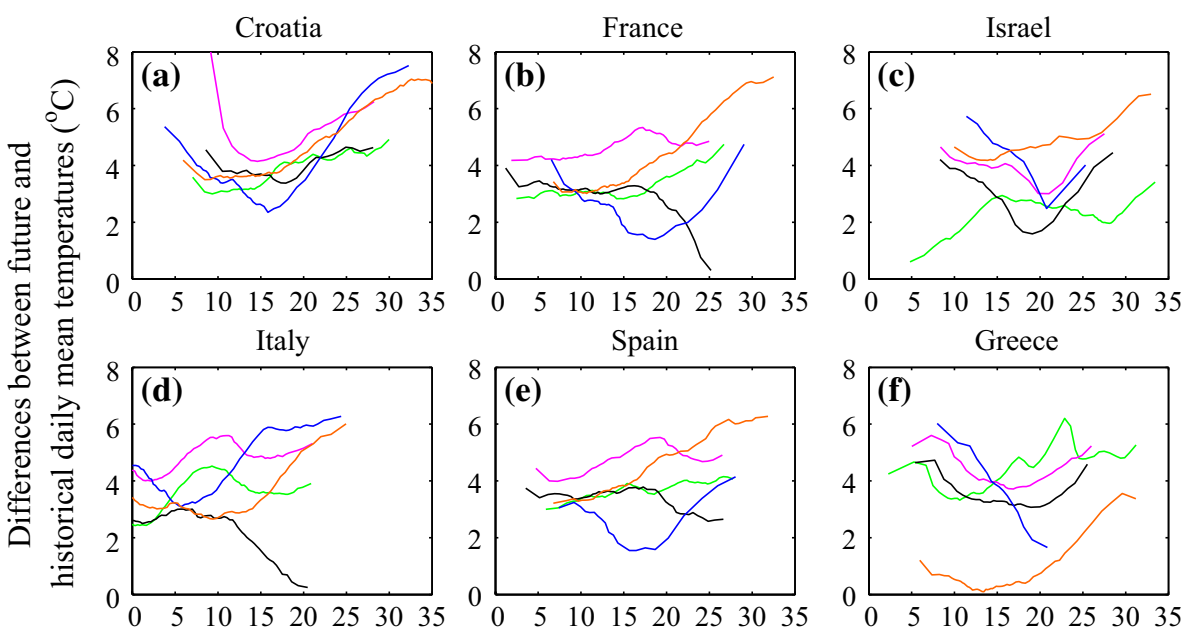

Daily mean temperature $\left({ }^{\circ} \mathrm{C}\right)$ respect to the temperature change are shown in Fig. 12 and are referred as the "adjusted historical" scaling of precipitation extremes. In other words, these "adjusted historical" curves are obtained by shifting the current climate curve along the $\mathrm{CC}$-slope by a shifting amplitude corresponding to the temperature change. They are compared to the curve from the historical simulations and the projected curve from the RCP8.5 simulations. The results are shown at the 6 surface weather stations using the simulations at $0.44^{\circ}$ resolution. The results show that the adjusted curves match fairly well the projected curves suggesting that despite a negative slope of the temperature-precipitation extremes relationship at high temperatures, the $\mathrm{CC}$ law seems to apply in a warming regional climate. In detail, the best recovery of the projected curve using the $\mathrm{CC}$ law are obtained in Spain, France, Italy and Croatia for all models.
The deviation of the "adjusted historical" scaling of precipitation extremes from the scaling in the future climate is larger in Greece, especially at high temperatures for ITURegCM4BATS-3-MED44, ITU-RegCM4CLM-3-MED44 and ICTP-RegCM4-3-MED44. In Israel, the "adjusted historical" scaling of precipitation extremes fits well the future scaling of precipitation extremes for ITU-RegCM4BATS3-MED44, ITU-RegCM4CLM-3-MED44 and LMDLMDZ4NEMO8-MED44, the latter fitting best the historical scaling of precipitation extremes at cold temperatures.

Changes in relative humidity can also impact the thermodynamic expectation described in Fig. 10. Figure 13 shows the relative humidity for the present and future climate from ITU-RegCM4CLM-3-MED44 simulation as a function of the daily mean temperature in the future climate. One single model is shown, but similar results were 
Fig. 12 Daily precipitation extremes (99th percentile) versus daily averaged future temperature at nearest grid point from the weather stations from the HyMeX/MED-CORDEX simulations at $0.44^{\circ}$ resolution (CNRM-ALADIN52-MED44: green; ITU-RegCM4BATS3-MED44: black; ITU-RegCM4CLM-3-MED44: magenta; ICTP-RegCM4-3-MED44: orange; LMD-LMDZ4NEMO8MED44: blue) driven by the downscaled simulations of the CMIP5 historical runs and RCP8.5 scenarios (Table 3). The thin solid line corresponds to the scaling of precipitation extremes with temperature computed from the RCP8.5 simulations, the thick solid line corresponds to the scaling of precipitation extremes computed from the historical runs and adjusted accounting for $\mathrm{CC}$ law and temperature change. The dashed curve corresponds to the scaling of precipitation extremes computed from the historical simulations
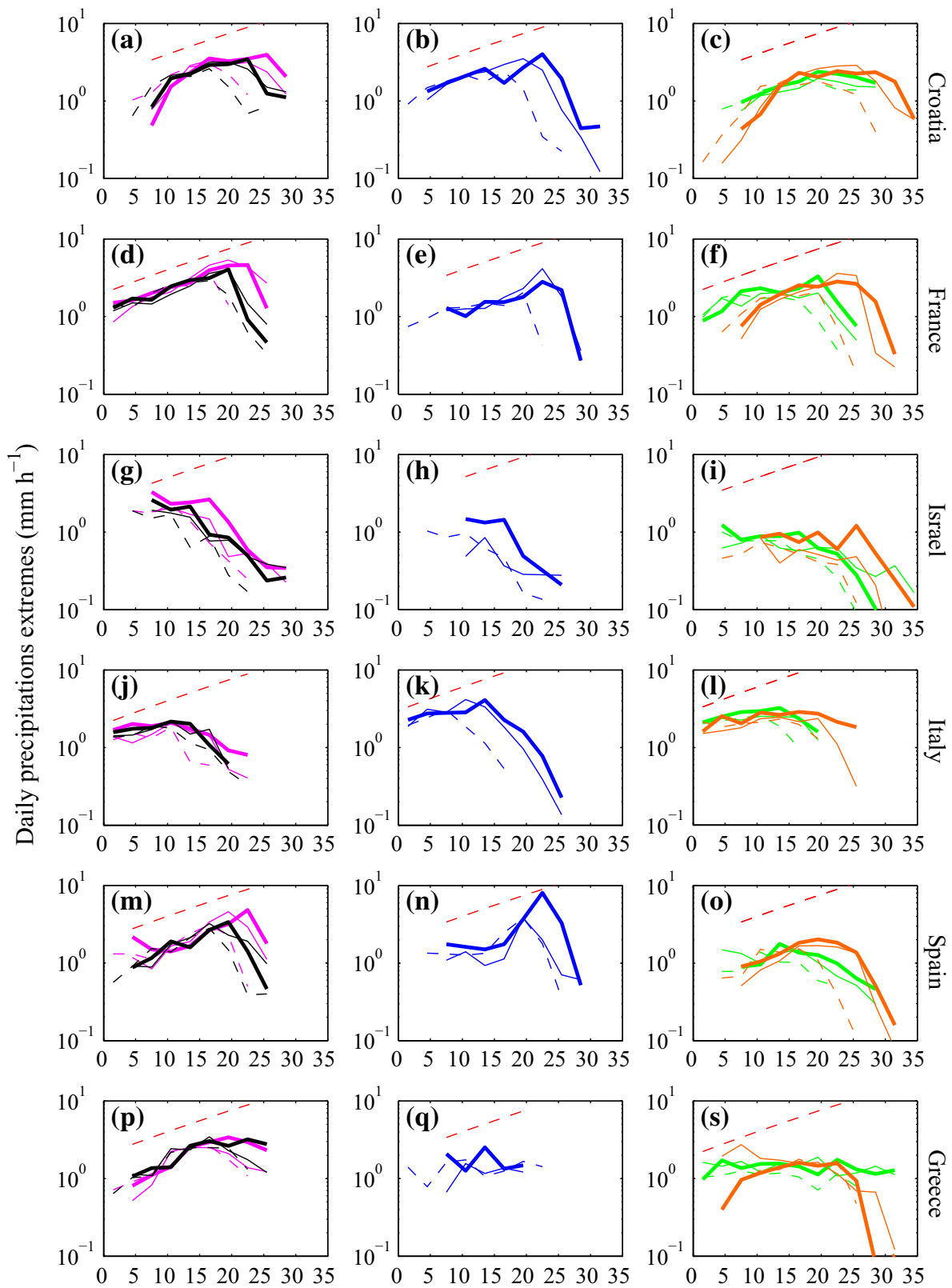

Daily mean temperature $\left({ }^{\circ} \mathrm{C}\right)$ obtained with the other models (not shown). Figure 13 also shows the "adjusted historical" relative humidity under the assumption of constant specific humidity. Note that all the relative humidity estimates, even the ones from historical runs, are plotted as a function of the future climate temperature to ease comparison. In addition to the 6 Mediterranean stations, one additional region in Central Europe was added to highlight the differences between the Mediterranean and the continental European climate, in principle less exposed to moisture advection from the oceans. Figure 13 clearly shows that for all Mediterranean stations, relative humidity does not change significantly in the future, even though in Israel, at high temperatures, the future relative humidity is slightly lower than in the present. Figure 13 also shows that the relative humidity is significantly different from the predicted relative humidity assuming constant specific humidity, which means that moisture sources from the oceans compensate the effect of increased temperature on relative humidity. Conversely, more continental regions can display a significant departure of the temperature-relative humidity relationship at high temperatures, as also shown in the work of Lenderink and Attema (2015). Figure 13 shows an example for a large region in Central and Eastern Europe (average over several hundreds of kilometers around Moscow). A decrease of relative humidity can be seen in this region far from large water bodies. At high temperature, the 
Fig. 13 Relative humidity in the future (blue) and present (red) climate as a function of daily mean future temperature at nearest ITU-RegCM4CLM3-MED44 grid point from the weather stations from the HyMeX/MED-CORDEX simulations at $0.44^{\circ}$ resolution driven by the CMIP5 historical simulations and RCP8.5 scenario performed by Hadgem2-ES. The green curve is the projected relative humidity in the absence of additional moisture source

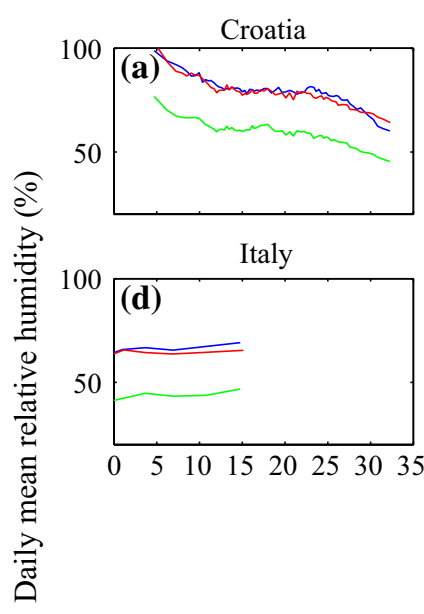

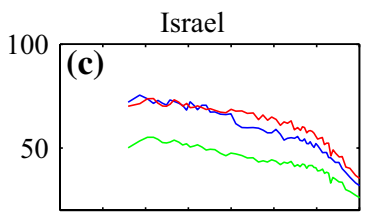

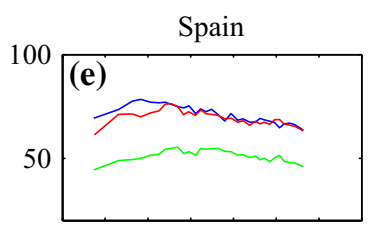

Central Europe

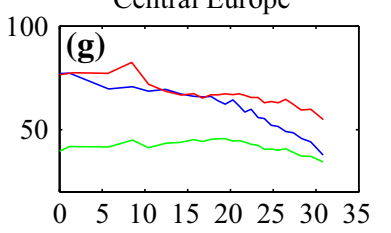

Daily mean temperature $\left({ }^{\circ} \mathrm{C}\right)$

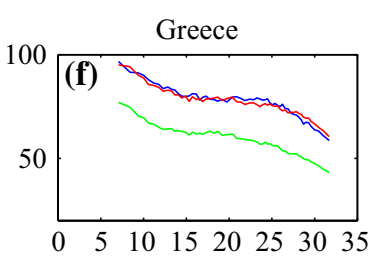

relative humidity in the future tends towards its adjusted value assuming no additional moisture sources (i.e. temperature change effect only). This suggests that at high temperatures in this region, the temperature increase associated with global climate change is not counter-balanced by an increase of humidity.

Why is such behavior not seen at the 6 Mediterranean weather stations is a key question. The Mediterranean Sea is actually a considerable moisture source for the region, and in a warmer future, evaporation is expected to increase with increasing temperature (Somot et al. 2006, 2008; Moratiel et al. 2011). Satellite observations show that the integrated water content over the oceans follows the CCscaling with respect to the sea surface temperature (e.g. Stephens 1990) due to energetic constraint (Schneider et al. 2010). Therefore the Mediterranean Sea is the primary source of humidity contributing to maintain the relative humidity constant over parts of the Euro-Mediterranean region. This is consistent with the study of Lebeaupin-Brossier et al. (2015) who showed that the response of precipitation to variations in sea surface temperature affects the continent over a horizontal scale limited by the surrounding mountain ranges.

Despite this finding, we note that the $\mathrm{CC}$ correction assuming constant relative humidity does not produce a full match between the adjusted and projected scalings of precipitation extremes. The differences may have various origins which are not accounted for by our simple scaling, such as model uncertainty (e.g. convection and microphysics parameterizations; Singh and O'Gorman 2012), change in precipitation duration (and thus impact on averaging effect), change in precipitation efficiency or vertical moisture transport in a more arid environment (Paltridge et al. 2009; Zhang 2009; Drobinski et al. 2016). The ratio of 3-hourly to daily precipitation extremes in the low-resolution simulations increases with warming (not shown), suggesting shorter extreme precipitation events and thus a steeper negative slope at high temperature for daily precipitation accumulation. However, the significance of these changes is not large.

\section{Conclusion}

Expected changes in future extreme precipitation remain a key uncertainty associated with anthropogenic climate change. Extreme precipitation has been proposed to scale with the precipitable water content in the atmosphere. Assuming constant relative humidity, this implies an increase of precipitation extremes at a rate of $7 \%{ }^{\circ} \mathrm{C}^{-1}$ as indicated by the Clausius-Clapeyron relationship. In this study, the scaling between precipitation extremes and temperature is investigated for the Mediterranean region by assessing against observations over the 1979-2008 period, ensembles of regional climate simulations performed within the frame of the HyMeX and MED-CORDEX programs. Despite quantitative differences in precipitation between the various models, the change in precipitation extremes with respect to temperature is robust and consistent across the models.

This study highlights the spatial variability of the scaling of precipitation extremes with temperature across the Mediterranean basin. In general, this scaling exhibits a hook shape with negative slope at high temperatures and a slope following CC-scaling at low temperatures. The temperature break, i.e. the temperature at which the slope sharply changes, ranges from about $20{ }^{\circ} \mathrm{C}$ in the western Mediterranean to $<10^{\circ} \mathrm{C}$ in Greece. It becomes undetectable further 
east and south of the Mediterranean, meaning that the slope is always negative in the arid regions of the Mediterranean. The scaling of precipitation extremes is insensitive to ocean-atmosphere coupling and it only slightly depends on resolution at high temperatures for short precipitation accumulation times (where precipitation is largely parameterized). This is due to the precipitation event duration differing at low and high resolutions at short time scales. However, such resolution effect is small and does not affect significantly the scaling of precipitation extremes with temperature.

Our study also investigates the evolution of this scaling in future climate scenario experiments over the 2070-2100 period. The temperature break shifts to higher temperatures by a value which is on average close to the mean regional temperature change due to global warming. The slope of the simulated temperature-precipitation extremes relationship is close to $\mathrm{CC}$-scaling at temperatures below the temperature break. At high temperatures, the curve can be flatter or steeper in the various models compared to present climate, i.e. some models exhibit more intense precipitation extremes in the future. The origin of the slope evolution is in agreement with the Clausius-Clapeyron law suggesting that the relative humidity remains constant in warming regional climate, with simply a distribution shifted to warmer temperature values. This may appear counter-intuitive since the Mediterranean is warming and drying at high rates, however this trend is not only simulated by global and regional climate models but also found in observations. The Mediterranean Sea is a large source of moisture for the region, and as atmospheric water vapor content increases with increasing temperature (following the Clausius-Clapeyron law) the Mediterranean Sea can maintain the relative humidity constant in a warming regional climate at least over a region under its influence. This region is limited by the numerous mountain ridges which surround the Mediterranean Sea, and in fact over continental Europe, at high temperatures, the relative humidity decreases significantly. This has implications for the scaling of precipitation extremes there (weaker extremes expected there at the highest temperatures due to water limitation).

The hook shape of the Mediterranean scaling of precipitation extremes with temperature is robust, and its present shape can be used to approximately predict the evolution of the precipitation extremes in a changing climate. Despite the hook shape deviating significantly from the $\mathrm{CC}$ scaling $\left(\sim 7 \%{ }^{\circ} \mathrm{C}^{-1}\right)$, its evolution appears to follow quite well the CC law. A natural follow-up of this study is (1) a detailed water budget evaluation to identify the humidity pathways that maintain constant relative humidity in parts of the Mediterranean region and (2) a thorough analysis of the climate change induced atmospheric circulation changes that cause precipitation extremes.
Acknowledgments This work is a contribution to the HyMeX program (HYdrological cycle in The Mediterranean EXperiment) through INSU-MISTRALS support and the Med-CORDEX program (COordinated Regional climate Downscaling EXperiment-Mediterranean region). This research has received funding from the French National Research Agency (ANR) projects REMEMBER (Contract ANR-12SENV-001) and STARMIP (contract ANR-12-JS06-0005). It was also supported by the IPSL group for regional climate and environmental studies, with granted access to the HPC resources of IDRIS (under allocation i2011010227). The authors are very grateful to M. Stéfanon and E. Flaounas for performing the WRF simulations as well as to the Meteorological Office of the Autonomous Province of Trento for providing stations data. This work has been partially funded by the Spanish Economy and Competitivity Ministry and the European Regional Development Fund, through Grants CGL2010-18013, CGL200766440-C04-02 and CGL2013-47261-R. The author's are grateful to Germán Solé (Observatori de l'Ebre) for his work on the Ebro Observatory's dataset. I. Guettler was partially supported by the Croatian Science Foundation, project CARE, No. 2831. They acknowledge the HyMeX database teams (ESPRI/IPSL and SEDOO/Observatoire Midi-Pyrénés) and the MED-CORDEX database team at ENEA for their help in accessing the data. It is also a contribution to the crosscutting activity on sub-daily precipitation of the GEWEX program of the World Climate Research Program (WCRP) (GEWEX Hydroclimate Panel). The authors gratefully acknowledge financial support from the Chair for Sustainable Development at Ecole Polytechnique.

Open Access This article is distributed under the terms of the Creative Commons Attribution 4.0 International License (http://creativecommons.org/licenses/by/4.0/), which permits unrestricted use, distribution, and reproduction in any medium, provided you give appropriate credit to the original author(s) and the source, provide a link to the Creative Commons license, and indicate if changes were made.

\section{References}

Allen MR, Ingram WJ (2002) Constraints on future changes in climate and the hydrological cycle. Nature 419:224-32

Alpert P, Ben-Gai T, Baharad A, Benjamini Y, Yekutieli D, Colacino M, Diodato L, Ramis C, Homar V, Romero R, Michaelides S, Manes A (2002) The paradoxical increase of Mediterranean extreme daily rainfall in spite of decrease in total values. Geophys Res Lett. doi:10.1029/2001GL013554

Baldauf M, Schulz JP (2004) Prognostic precipitation in the LokalModell (LM) of DWD. COSMO Newslett 4:177-180

Berg P, Moseley C, Haerter JO (2013a) Strong increase in convective precipitation in response to higher temperatures. Nat Geosci 6:181-185

Berg P, Haerter JO (2013b) Unexpected increase in precipitation intensity with temperature-a result of mixing precipitation types? Atmos Res 119:56-61

Berg P, Haerter JO, Thejll P, Piani C, Hagemann S, Christensen JH (2009) Seasonal characteristics of the relationship between daily precipitation intensity and surface temperature. J Geophys Res 114:D18102. doi:10.1029/2009JD012008

Berthou S, Mailler S, Drobinski P, Arsouze T, Bastin S, Béranger K, Lebeaupin-Brossier C (2015) Sensitivity of an intense rain event between an atmosphere-only and an atmosphere-ocean coupled model: 19 September 1996. Q J R Meteorol Soc 141:258-271

Berthou S, Mailler S, Drobinski P, Arsouze T, Bastin S, Béranger K, Lebeaupin-Brossier C (2014) Prior history of mistral and tramontane winds modulates heavy precipitation events in Southern France. Tellus 66:24064 
Betts AK, Harshvardhan (1987) Thermodynamic constraint on the cloud liquid water feedback in climate models. J Geophys Res 92:8483-8485

Bougeault P (1985) A simple parameterization of the largescale effects of cumulus convection. Mon Weather Rev 113:2108-2121

Chen CT, Knutson T (2008) On the verification and comparison of extreme rainfall indices from climate models. J Clim 21:1605-1621

Colin J, Déqué M, Radu R, Somot S (2010) Sensitivity study of heavy precipitation in limited area model climate simulations: influence of the size of the domain and the use of the spectral nudging technique. Tellus 62A:591-604

Cuxart J, Bougeault P, Redelsperger JL (2000) A turbulence scheme allowing for mesoscale and large-eddy simulations. Q J R Meteorol Soc 126:1-30

Delrieu G, Nicol J, Yates E, Kirstetter PE, Creutin JD, Anquetin S, Obled C, Saulnier GM, Ducrocq V, Gaume E, Payrastre O, Andrieu H, Ayral PA, Bouvier C, Neppel L, Livet M, Lang M, Parent du-Châtelet J, Walpersdorf A, Wobrock W (2005) The catastrophic flash-flood event of 8-9 September 2002 in the Gard region, France: a first case study for the CevennesVivarais Mediterranean Hydro-meteorological Observatory. J Hydrometeorol 6:34-52

Déqué M, Jones RG, Wild M, Giorgi F, Christensen JH, Hassell DC, Vidale PL, Rockel B, Jacob D, Kjellstrom E, de Castro M, Kucharski F, van den Hurk B (2005) Global high resolution versus limited area model scenarios over Europe: results from the PRUDENCE project. Clim Dyn 25:653-670

Dickinson RE, Henderson-Sellers A, Kennedy P (1993) Biosphereatmosphere transfer scheme (BATS) version 1e as coupled to the NCAR community climate model. Technical report, National Center for Atmospheric Research Technical Note NCAR. TN-387+STR, NCAR, Boulder, CO

Doms G, Förstner J, Heise E, Herzog H-J, Raschendorfer M, Schrodin R, Reinhardt T, Vogel G (2007) A description of the nonhydrostatic regional model LM. Part II: physical parameterization. http://www.cosmomodel.org/content/model/documentation/ core/cosmoPhysParamtr

Drobinski P, Alonzo B, Bastin S, Da Silva N, Muller CJ (2016) Scaling of precipitation extremes with temperature in the French Mediterranean region: what explains the hook shape? J Geophys Res. doi:10.1002/2015JD023497

Drobinski P, Ducrocq V, Alpert P, Anagnostou E, Béranger K, Borga M, Braud I, Chanzy A, Davolio S, Delrieu G, Estournel C, Filali Boubrahmi N, Font J, Grubisic V, Gualdi S, Homar V, IvancanPicek B, Kottmeier C, Kotroni V, Lagouvardos K, Lionello P, Llasat MC, Ludwig W, Lutoff C, Mariotti A, Richard E, Romero R, Rotunno R, Roussot O, Ruin I, Somot S, TaupierLetage I, Tintore J, Uijlenhoet R, Wernli H (2014) HyMeX, a 10-year multidisciplinary program on the Mediterranean water cycle. Bull Am Meteorol Soc 95:1063-1082

Drobinski P, Anav A, Lebeaupin Brossier C, Samson G, Stéfanon M, Bastin S, Baklouti M, Béranger K, Beuvier J, BourdalléBadie R, Coquart L, D'Andrea F, De Noblet-Ducoudré N, Diaz F, Dutay JC, Ethe C, Foujols MA, Khvorostyanov D, Madec G, Mancip M, Masson S, Menut L, Palmieri J, Polcher J, Turquety S, Valcke S, Viovy N (2012) Modelling the Regional Coupled Earth system (MORCE): application to process and climate studies in vulnerable regions. Environ Modell Softw 35:1-18

Ducrocq V, Nuissier O, Ricard D, Lebeaupin C, Thouvenin T (2008) A numerical study of three catastrophic precipitating events over southern France. Part II: mesoscale trigerring and stationarity factors. Q J R Meteorol Soc 134:131-145
Dudhia J (1989) Numerical study of convection observed during the winter monsoon experiment using a mesoscale two-dimensional model. J Atmos Sci 46:3077-3107

Emanuel KA (1993) A cumulus representation based on the episodic mixing model: the importance of mixing and microphysics in predicting humidity. AMS Meteorol Monogr 24:185-192

Flaounas E, Drobinski P, Vrac M, Bastin S, Lebeaupin-Brossier C, Stéfanon M, Borga M, Calvet JC (2013) Precipitation and temperature space-time variability and extremes in the Mediterranean region: evaluation of dynamical and statistical downscaling methods. Clim Dyn 40:2687-2705

Flaounas E, Drobinski P, Borga M, Calvet JC, Delrieu G, Morin E, Tartari G, Toffolon R (2012) Assessment of gridded observations used for climate model validation in the Mediterranean region: the HyMeX and MED-CORDEX framework. Environ Res Lett. doi:10.1088/1748-9326/7/2/024017

Fouquart Y, Bonnel B (1980) Computations of solar heating of the Earth's atmosphere: a new parametrization. Contrib Atmos Phys 53:35-62

Gao X, Pal JS, Giorgi F (2006) Projected changes in mean and extreme precipitation over the Mediterranean region from high resolution double nested RCM simulation. Geophys Res Lett 33:L03706. doi:10.1029/2005GL024954

Gibelin AL, Déqué M (2003) Anthropogenic climate change over the Mediterranean region simulated by a global variable resolution model. Clim Dyn 20:327-339

Giorgi F (2006) Climate change hot-spots. Geophys Res Lett 33:L08707. doi:10.1029/2006GL025734

Giorgi F, Bi X (2005) Updated regional precipitation and temperature changes for the 21st century from ensembles of recent AOGCM simulations. Geophys Res Lett 32:L21715. doi:10.1029/200 5GL024288

Grell GA (1993) Prognostic evaluation of assumptions used by cumulus parameterizations. Mon Weather Rev 121:764-787

Hardwick Jones R, Westra S, Sharma A (2010) Observed relationships between extreme sub-daily precipitation, surface temperature, and relative humidity. Geophys Res Lett 37:L22805. doi:1 0.1029/2010GL045081

Haerter JO, Berg P (2009) Unexpected rise in extreme precipitation caused by a shift in rain type? Nat Geosci 2:372-373

Haylock MR, Hofstra N, Klein Tank AMG, Klok EJ, Jones PD, New M (2008) A European daily high-resolution gridded data set of surface temperature and precipitation for 1950-2006. J Geophys Res 113:D20119

Held IM, Soden BJ (2006) Robust responses of the hydrological cycle to global warming. J Clim 19:5686-5699

Herrera S, Gutiérrez JM, Ancell R, Pons MR, Frías MD, Fernandez J (2012) Development and analysis of a 50-year high-resolution daily gridded precipitation dataset over Spain (Spain02). Int J Climatol 32:74-85

Herrmann M, Somot S, Calmanti S, Dubois C, Sevault F (2011) Representation of spatial and temporal variability of daily wind speed and of intense wind events over the Mediterranean sea using dynamical downscaling: impact of the regional climate model configuration. Nat Hazards Earth Syst Sci 11:1983-2001

Hofstra N, Haylock M, New M, Jones P (2009) Testing E-OBS European high-resolution gridded data set of daily precipitation and surface temperature. J Geophys Res 114(D21): 101

Hofstra N, New M, McSweeney C (2010) The influence of interpolation and station network density on the distributions and trends of climate variables in gridded daily data. Clim Dyn 35:841-858

Holtslag A, de Bruijn E, Pan HL (1990) A high resolution air mass transformation model for short-range weather forecasting. Mon Weather Rev 118:1561-1575 
Hong SY, Dudhia J, Chen SH (2004) A revised approach to ice microphysical processes for the bulk parameterization of clouds and precipitation. Mon Weather Rev 132:103-120

Hourdin F, Musat I, Bony S, Braconnot P, Codron F, Dufresne JL, Fairhead L, Filiberti MA, Friedlingstein P, Grandpeix JY (2006) The LMDZ4 general circulation model: climate performance and sensitivity to parametrized physics with emphasis on tropical convection. Clim Dyn 27:787-813

IPCC (2013) Climate Change 2013: the physical science basis. In: Stocker TF, Qin D, Plattner G-K, Tignor M, Allen SK, Boschung J, Nauels A, Xia Y, Bex V, Midgley PM (eds) Contribution of Working Group I to the Fifth Assessment Report of the Intergovernmental Panel on Climate Change. Cambridge University Press, Cambridge

Jonkman SN (2005) Global perspectives on loss of human life caused by floods. Nat Hazards 34:151-175

Kain JS (2004) The Kain-Fritsch convective parameterization: an update. J Appl Meteorol 43:170-181

Kharin VV, Zwiers FW, Zhang X, Hegerl GC (2007) Changes in temperature and precipitation extremes in the IPCC ensemble of global coupled model simulations. J Clim 20:1419-1444

Kiehl J, Hack J, Bonan G, Boville B, Breigleb B, Williamson D, Rasch P (1996) Description of the NCAR community climate model (CCM3). National Center for Atmospheric Research Tech Note NCAR/TN-420+STR, NCAR, Boulder, CO

Kjellström E, Nikulin G, Hansson U, Strandberg G, Ullerstig A (2011) 21st Century changes in the European climate: uncertainties derived from an ensemble of regional climate model simulations. Tellus A 63:24-40

Klok E, Klein Tank A (2009) Updated and extended European dataset of daily climate observations. Int J Climatol 29:1182-1191

Krinner G, Viovy N, de Noblet-Ducoudré N, Ogée J, Polcher J, Friedlingstein P, Ciais P, Sitch S, Prentice C (2005) A dynamic global vegetation model for studies of the coupled atmospherebiosphere system. Glob Biogeochem Cycles 19:GB1015. doi:10.1029/2003GB002199k

Kysel J, Plavcov E (2010) A critical remark on the applicability of E-OBS European gridded temperature data set for validating control climate simulations. J Geophys Res 115(D23):118

Lavaysse C, Vrac M, Drobinski P, Vischel T, Lengaigne M (2012) Statistical downscaling of the French Mediterranean climate: assessment for present and projection in an anthropogenic scenario. Nat Hazards Earth Syst Sci 12:651-670

Lebeaupin-Brossier C, Drobinski P, Béranger K, Bastin S (2015) Regional mesoscale air-sea coupling impacts and extreme meteorological events role on the Mediterranean Sea water budget. Clim Dyn 44:1029-1051

Lebeaupin-Brossier C, Drobinski P, Béranger K, Bastin S, Orain F (2013) Ocean memory effect on the dynamics of coastal heavy precipitation preceded by a mistral event in the North-Western Mediterranean. Q J R Meteorol Soc 139:1583-1597

Lebeaupin Brossier C, Béranger K, Drobinski P (2012) Sensitivity of the north-western Mediterranean coastal and thermohaline circulations as simulated by the $1 / 12^{\circ}$ resolution oceanic model NEMO-MED12 to the space-time resolution of the atmospheric forcing. Ocean Model 43-44:94-107

Lebeaupin Brossier C, Béranger K, Drobinski P (2012) Ocean response to strong precipitation events in the Gulf of Lions (north-western Mediterranean Sea): a sensitivity study. Ocean Dyn 62:213-226

Lebeaupin Brossier C, Béranger K, Deltel C, Drobinski P (2011) The Mediterranean response to different space-time resolution atmospheric forcings using perpetual mode sensitivity simulations. Ocean Model 36:1-25

Lenderink G, Attema J (2015) A simple scaling approach to produce climate scenarios of local precipitation extremes for the Netherlands. Environ Res Lett 10:085001. doi:10.1088/1748-9326/10/8/085001

Lenderink G, van Meijgaard E (2008) Increase in hourly precipitation extremes beyond expectations from temperature changes. Nat Geosci 1:511-514

Li ZX (1999) Ensemble atmospheric GCM simulation of climate interannual variability from 1979 to 1994. J Clim 12:986-1001

Lorenz P, Jacob D (2010) Validation of temperature trends in the ENSEMBLES regional climate model runs driven by ERA40. Clim Res 44:167-177

Loriaux JM, Lenderink G, De Roode SR, Siebesma AP (2013) Understanding convective extreme precipitation scaling using observations and an entraining plume model. J Atmos Sci 70:3641-3655

Louis J-F (1979) A parametric model of vertical eddy fluxes in the atmosphere. Bound Layer Meteorol 17:187-202

Maeda EE, Utsumi N, Oki T (2012) Decreasing precipitation extremes at higher temperatures in tropical regions. Nat Hazards 64:935-941

Mamara A, Argiriou A, Anadranistakis M (2013) Homogenization of mean monthly temperature time series of Greece. Int J Climatol 33:2649-2666

Meehl GA, Stocker TF, Collins WD, Friedlingstein P, Gaye AT, Gregory JM, Kitoh A, Knutti R, Murphy JM, Noda A, Raper SCB, Watterson IG, Weaver AJ, Zhao ZC (2007) Global climate projections. In: Solomon S, Qin D, Manning M, Chen Z, Marquis M, Averyt KB, Tignor M, Miller HL (eds) Climate Change 2007: the physical science basis. Contribution of Working Group I to the Fourth Assessment Report of the Intergovernmental Panel on Climate Change. Cambridge University Press, Cambridge

Min SK, Zhang X, Zwiers FW, Hegerl GC (2011) Human contribution to more-intense precipitation extremes. Nature 470:378-381

Mlawer EJ, Taubnam SJ, Brown PD, Iacono MJ, Clough SA (1997) A validated correlated k-model for the longwave. J Geophys Res 102:16663-16682

Moratiel R, Snyder RL, Duran JM, Tarquis AM (2011) Trends in climatic variables and futur reference evapotranspiration in Duero Valley (Spain). Nat Hazards Earth Syst 11:1795-1805

Morcrette JJ, Barker H, Cole J, Iacono M, Pincus R (2008) Impact of a new radiation package, McRad, in the ECMWF Integrated Forecasting System. Mon Weather Rev 136:4773-4798

Morcrette JJ (1990) Impact of changes to the radiation transfer parameterizations plus cloud optical properties in the ECMWF model. Mon Weather Rev 118:847-873

Morcrette JJ, Smith L, Fouquart Y (1986) Pressure and temperature dependence of the absorption in longwave radiation parametrizations. Contrib Atmos Phys 59:455-469

Muller C (2013) Impact of convective organization on the response of tropical precipitation extremes to warming. J Clim 26:5028-5043

Muller CJ, O'Gorman PA, Back LE (2011) Intensification of precipitation extremes with warming in a cloud resolving model. J Clim 24:2784-2800

Nikulin G, Kjellström E, Hansson U, Strandberg G, Ullerstig A (2011) Evaluation and future projections of temperature, precipitation and wind extremes over Europe in an ensemble of regional climate simulations. Tellus A 63:41-55

Noh Y, Cheon WG, Hong SY, Raasch S (2003) Improvement of the $\mathrm{k}$-profile model for the planetary boundary layer based on large eddy simulation data. Bound Layer Meteorol 107:401-427

Noilhan J, Mahfouf J-F (1996) The ISBA land surface parameterisation scheme. Glob Planet Change 13:145-159

Noilhan J, Planton S (1989) A simple parameterization of land surface processes for meteorological models. Mon Weather Rev 117:536-549 
Norbiato D, Borga M, Dinale R (2009) Flash flood warning in ungauged basins by use of the Flash Flood Guidance and model-based runoff thresholds. Meteorol Appl 16:65-75

O'Gorman PA, Muller CG (2010) How closely do changes in surface and column water vapour follow Clausius-Clapeyron scaling in climate change simulations? Environ Res Lett 5(025):207

O'Gorman PA, Schneider E (2009) Scaling of precipitation extremes over a wide range of climates simulated with an idealised GCM. J Clim 22:5676-5685

Oki T, Kanae S (2006) Global hydrological cycles and world water resources. Science 313:1068-1072

Oleson KW, Niu G-Y, Yang Z-L, Lawrence DM, Thornton PE, Lawrence PJ, Stöckli R, Dickinson RE, Bonan GB, Levis S, Dai A, Qian T (2008) Improvements to the Community Land Model and their impact on the hydrological cycle. J Geophys Res 113:G01021. doi:10.1029/2007JG000563

Omrani H, Drobinski P, Dubos T (2015) Using nudging to improve global-regional dynamic consistency in limited-area climate modeling: what should we nudge? Clim Dyn 44:1627-1644

Omrani H, Drobinski P, Dubos T (2013) Optimal nudging strategies in regional climate modelling: investigation in a Big-Brother Experiment over the European and Mediterranean regions. Clim Dyn 41:2451-2470

Önol B, Bozkurt D, Turuncoglu UU, Sen OL, Dalfes HN (2014) Evaluation of the 21 st century RCM simulations driven by multiple GCMs over the Eastern Mediterranean-Black Sea region. Clim Dyn 42:1949-1965

Pal JS, Giorgi F, Bi X (2004) Consistency of recent European summer precipitation trends and extremes with future regional climate projections. Geophys Res Lett 31:L13202. doi:10.1029/2 004GL019836

Pal JS, Small E, Eltahir E (2000) Simulation of regional-scale water and energy budgets: representation of subgrid cloud and precipitation processes within RegCM. J Geophys Res 105:29579-29594

Pall P, Aina T, Stone DA, Stott PA, Nozawa T, Hilberts AGJ, Lohmann D, Allen MR (2011) Anthropogenic greenhouse gas contribution to flood risk in England and Wales in autumn 2000. Nature 470:382-385

Pall P, Allen MR, Stone DA (2007) Testing the Clausius-Clapeyron constraint on changes in extreme precipitation under $\mathrm{CO}_{2}$ warming. Clim Dyn 28:351-363

Paltridge G, Arking A, Pook M (2009) Trends in middle- and upperlevel tropospheric humidity from NCEP reanalysis data. Theor Appl Climatol 98:351-359

Panziera L, Giovannini L, Laiti L, Zardi D (2015) The relation between circulation types and regional Alpine climate. Part I: synoptic climatology of Trentino. Int J Climatol. doi:10.1002/ joc. 4314

Papagiannaki K, Lagouvardos K, Kotroni V (2013) A database of high-impact weather events in Greece: a descriptive impact analysis for the period 2001-2011. Nat Hazards Earth Syst Sci 13:727-736

Quereda Sala J, Gil Olcina A, Perez Cuevas A, Olcina Cantos J, Rico Amoros A, Montón Chiva E (2000) Climatic warming in the Spanish Mediterranean: natural trend or urban effect. Clim Chang 46:473-483

Ricard JL, Royer JF (1993) A statistical cloud scheme for use in an AGCM. Ann Geophys 11:1095-1115

Ritter B, Geleyn J-F (1992) A comprehensive radiation scheme of numerical weather prediction with potential application to climate simulations. Mon Weather Rev 120:303-325

Rockel B, Will A, Hense A (eds) (2008) The regional climate model COSMO-CLM (CCLM). Meteorol Z 17:347-348

Romps DM (2011) Response of tropical precipitation to global warming. J Atmos Sci 68:123-138
Ruti P, Somot S, Giorgi F, Dubois C, Flaounas E, Obermann A, Dell'Aquila A, Pisacane G, Harzallah A, Lombardi E, Ahrens B, Akhtar N, Alias A, Arsouze T, Raznar R, Bastin S, Bartholy J, Béranger K, Beuvier J, Bouffies-Cloche S, Brauch J, Cabos W, Calmanti S, Calvet JC, Carillo A, Conte D, Coppola E, Djurdjevic V, Drobinski P, Elizalde A, Gaertner M, Galan P, Gallardo C, Gualdi S, Goncalves M, Jorba O, Jorda G, Lheveder B, Lebeaupin-Brossier C, Li L, Liguori G, Lionello P, Macias-Moy D, Onol B, Rajkovic B, Ramage K, Sevault F, Sannino G, Struglia MV, Sanna A, Torma C, Vervatis V (2015) MED-CORDEX initiative for Mediterranean climate studies. Bull Am Meteorol Soc. doi:10.1175/BAMS-D-14-00176.1

Salameh T, Drobinski P, Dubos T (2010) The effect of indiscriminate nudging time on the large and small scales in regional climate modelling: application to the Mediterranean Basin. Q J R Meteorol Soc 136:170-182

Samuelsson P, Jones C, Willén U, Ullerstig A, Gollvik S, Hansson U, Jansson C, Kjellström E, Nikulin G, Wyser K (2011) The Rossby Centre Regional Climate model RCA3: model description and performance. Tellus A 63:4-23

Schneider T, O'Gorman PA, Levine XJ (2010) Water vapor and the dynamics of climate changes. Rev Geophys 48:RG3001. doi:10.1029/2009RG000302

Seguí-Grau J (2003) Análisis de la Serie de Temperatura del Observatorio del Ebro (1894-2002). Publicaciones de l'Observatori de l'Ebre. Miscel.lània; 44, Observatori de l'Ebre, Roquetes (Tarragona)

Shohami D, Dayan U, Morin E (2011) Warming and drying of the eastern Mediterranean: additional evidence from trend analysis. J Geophys Res 116:D22101. doi:10.1029/2011JD016004

Singh MS, O’Gorman PA (2012) Influence of microphysics on the scaling of precipitation extremes with temperature. Geophys Res Lett. doi:10.1002/2014GL061222

Singleton A, Toumi R (2013) Super-Clausius-Clapeyron scalnig of rainfall in a model squall line. Q J R Meteorol Soc 139:334-339

Skamarock WC, Klemp JB, Dudhia J, Gill DO, Barker DM, Duda MG, Huang XY, Wang W, Powers JG (2008) A description of the advanced research WRF version 3. Technical Report, NCAR

Smirnova TG, Brown JM, Benjamin SG (1997) Performance of different soil model configurations in simulating ground surface temperature and surface fluxes. Mon Weather Rev 125:1870-1884

Smith RNB (1990) A scheme for predicting layer clouds and their water content in a general circulation model. Q J R Meteorol Soc 116:435-460

Solomon S, Qin D, Manning M, Alley RB, Berntsen T, Bindoff NL, Chen Z, Chidthaisong A, Gregory JM, Hegerl GC, Heimann M, Hewitson B, Hoskins BJ, Joos F, Jouzel J, Kattsov V, Lohmann U, Matsuno T, Molina M, Nicholls N, Overpeck J, Raga G, Ramaswamy V, Ren J, Rusticucci M, Somerville R, Stocker TF, Whetton P, Wood RA, Wratt D (2007) Technical summary. In: Solomon S, Qin D, Manning M, Chen Z, Marquis M, Averyt KB, Tignor M, Miller HL (eds) Climate change 2007: the physical science basis. Contribution of Working Group I to the Fourth Assessment Report of the Intergovernmental Panel on Climate Change. Cambridge University Press, Cambridge

Somot S, Sevault F, Déqué M, Crépon M (2008) 21st century climate change scenario for the Mediterranean using a coupled atmosphere-ocean regional climate model. Glob Planet Change 63:112-126

Somot S, Sevault F, Déqué M (2006) Transient climate change scenario simulation of the Mediterranean Sea for the 21st century using a high-resolution ocean circulation model. Clim Dyn 27:851-879

Stéfanon M, Drobinski P, D'Andrea F, Lebeaupin-Brossier C, Bastin S (2014) Soil moisture-temperature feedbacks at 
meso-scale during heat waves over Western Europe. Clim Dyn 42:1309-1324

Stephens G (1990) On the relationship between water vapor over the oceans and sea surface temperature. J Clim 3:634-645

Sugiyama M, Shiogama H, Emori S (2010) Precipitation extreme changes exceeding moisture content increases in MIROC and IPCC climate models. Proc Natl Acad Sci 107:571-575

Tiedtke M (1989) A comprehensive mass flux scheme for cumulus parameterization in large-scale models. Mon Weather Rev 117:1779-1799

Torma C, Coppola E, Giorgi F, Bartholy J, Pongrcz R (2011) Validation of a high-resolution version of the regional climate model RegCM3 over the Carpathian basin. J Hydrometeorol 12:84-100

Trenberth KE, Dai A, Rasmussen RM, Parsons DB (2003) The changing character of precipitation. Bull Am Meteorol Soc 84:1205-1217

Turco M, Marcos R, Quintana-Seguí P, Llasat MC (2014) Testing instrumental and downscaled reanalysis time series for temperature trends in NE of Spain in the last century. Reg Environ Change 14:1811-1823

Ulbrich U, May W, Lionello P, Pinto JG, Somot S (2006) The Mediterranean climate change under global warming (chapter 8). In: Lionello P, Malanotte P, Boscolo R (eds) Mediterranean climate variability. Elsevier B.V, Amsterdam, pp 399-415
Utsumi N, Seto S, Kanae S, Maeda EE, Oki T (2011) Does higher surface temperature intensify extreme precipitation? Geophys Res Lett 38:L16708

Westra S, Fowler HJ, Evans JP, Alexander LV, Berg P, Johnson F, Kendon EJ, Lenderink G, Roberts NM (2014) Future changes to the intensity and frequency of short-duration extreme rainfall. Rev Geophys. doi:10.1002/2014RG000464

Xoplaki E, Gonzales-Rouco FJ, Luterbacher J, Wanner H (2003) Mediterranean summer air temperature variability and its connection to the large-scale atmospheric circulation and SSTs. Clim Dyn 20:723-739

Zahumensky I (2010) Guidelines for quality control procedures applying to data from automatic weather stations. In: World meteorological organization report No. 488, Guide to the global observing system, Appendix VI.2. WMO, Geneva

Zaninovic K, Gajic-Capka M, Percec Tadic M, Vucetic M, Milkovic J, Bajic A, Cindric K, Cvitan L, Katusin Z, Kaucic D, Likso T, Loncar E, Loncar Z, Mihajlovic D, Pandzic K, Patarcic M, Srnec L, Vucetić V (2008) Climate atlas of Croatia 1961-1990, 1971-2000. Meteorological and Hydrological Service (DHMZ), Zagreb, p 200

Zhang GJ (2009) Effects of entrainment on convective available potential energy and closure assumptions in convection parameterization. J Geophys Res 114:D07109. doi:10.1029/200 8JD010976 